\title{
Rulemaking Under the Illinois Pollution Law
}

\author{
David P. Currie $\dagger$
}

Conceived at the height of the ecological movement in 1970, the Illinois Environmental Protection Act ${ }^{1}$ essayed a thorough revision of the state's rather somnolent mechanism for pollution control. Drawn into a unified program were formerly scattered powers over air pollution, water pollution, solid-waste disposal, and public water supplies, along with a brand-new power to regulate noise. Three new agencies were created, with powers divided on functional lines. In order to separate prosecutor from judge, the Environmental Protection Agency was to file complaints and the independent Pollution Control Board to decide them, while the Institute for Environmental Quality was to engage in relatively long-term planning, free from the distractions of everyday enforcement duties. Rulemaking authority was given to the Board, not so much out of abstract public-administration principles as to assure that the authority would be exercised vigorously: it was known in the drafting stage that the Agency would necessarily be manned largely by the staffs of the previous agencies and headed by the longtime chief of staff to the old air and water boards, while the new Board would be chosen afresh by the Governor.

Eliminated from the new statute were earlier provisions requiring certain Board members to be representatives of executive departments, of affected interest groups such as industry, or of specified professions: the first were thought to endanger the separation of Board from prosecutor, the second to create conflicts of interest, and the third to imply erroneously that certain professions possessed a monopoly of relevant information. Board membership was made a full-time job, in contrast to the previous volunteer Boards whose members could not devote adequate time to a very demanding assignment. Rulemaking authority was broadened; greater provision was made for public participation, including public access to most information in government files and the right of citizens to

$\dagger$ Professor of Law, The University of Chicago; Illinois Coordinator of Environmental Quality, 1970; Chairman, Illinois Pollution Control Board, 1970-72. Copyright 1975 by the author.

1 Ill. Rev. StAT. ch. 111 1/2, $\$$ 1001-50 (1973) (originally enacted as Pub. Act No. 76-2429, May 29, 1970, 1970 Ill. Laws 873 ) [hereinafter cited by section number only]. 
enforce the law and regulations by filing complaints; the Board was authorized to impose money penalties for violations; procedures for exempting localities from the operation of state law were eliminated.

The result was a statutory framework that has sustained a flurry of rulemaking and enforcement activity. During the five years since the statute's adoption, enough experience has accumulated to permit a preliminary assessment of the system that was established. Having largely drafted the Act and presided for two and a half years over the Board it created, I am a wholly biased observer. My opinions, therefore, are to be taken with more than the usual dose of skepticism; my excuse for writing is the hope that, having been on the inside of the process, I may be able to expose some of the facts about its operation that are not otherwise easily accessible. ${ }^{2}$

The present article deals with the substantive and procedural aspects of rulemaking under the Environmental Protection Act, while a later paper will discuss the enforcement process. The result is intended to afford a view of the Illinois program both in its details and as a unified whole, for the benefit not only of those directly affected by the statute but also of those concerned with devising or operating pollution-control programs elsewhere, for the problems encountered in Illinois are universal.

\section{The Statutory Framework}

The basic plan of the statute is to leave the formulation of substantive standards to the Board, not to enshrine them in the statute itself. The reason for this choice was the expectation that specialized administrators working full time on pollution problems would be in a better position than legislators burdened by innumerable other concerns to make reasonable judgments based upon masses of relevant technical information. The heart of the statute, therefore, is a series of grants of authority to make whatever regulations may be necessary to accomplish the explicit purposes set forth by the General Assembly: for example, "to restore, maintain, and

${ }^{2}$ For a generally favorable assessment of the statutory framework by somewhat less partial observers, see E. Haskell \& V. Price, State Environmental Management ch. 1 (1973). The authors express concern lest the separation of powers among the three agencies disable them from taking effective action. I acknowledge that there were times when as Chairman of the Board I wished I had power to file complaints or to undertake extensive studies looking toward the development of regulations, but efficiency is not the only concern in devising government institutions. 
enhance the purity" of air and water "in order to protect health, welfare, and the quality of life"; 3 and "to prevent the pollution or misuse of land, to promote the conservation of natural resources and minimize environmental damage by reducing the difficulty of disposal of wastes and encouraging and effecting the re-cycling and reuse of waste materials." Extensive lists of particular categories of permissible regulations-air and water quality standards, emission and effluent standards, permit and monitoring requirements, and so forth ${ }^{5}$-are intended only to provide illustrations and to avoid any possibility of exclusion through narrow construction, "without limiting the generality" of the basic grant of authority. ${ }^{6}$ Section 27 , which makes clear that regulations may make necessary distinctions between "different contaminant sources" or "different geographical areas" and may govern out-of-state sources contributing to or threatening environmental damage in Illinois, also contains the essential limiting constraints on Board pursuit of the statutory objective of a clean environment: in adopting regulations the Board "shall take into account . . . the technical feasibility and economic reasonableness of measuring or reducing the particular type of pollution." Thus in general the Board is authorized to embody in regulations such limitations on human activities as are justifiable in light of the severity of the environmental damage to be avoided and the cost of avoiding it.

The bill as originally drafted ${ }^{7}$ would have tilted the scales more heavily against pollution. There was, for example, no express requirement that the feasibility or cost of abatement be considered in adopting regulations. It might nevertheless have been possible to read the injunction to "protect health, welfare, property and the quality of life" not to preclude compromises based upon such an obviously relevant consideration as cost, had the bill said no more. The draft had further prescribed that effluent and emission standards require "the best practicable treatment or control." "Practicable" is a flexible word that can easily be read, in contrast to "feasible," to import some consideration of cost; but it might readily have been held to require the employment of a given level of control technology statewide without regard to widely different benefits. As I shall discuss below, ${ }^{8}$ the Board sometimes prescribed uniform

\footnotetext{
$3 \S \S 8,10,11,13$.

- $\S \S 20,22$.

s E.g., $\$ \S 10,13$.

- Id.

7 H.B. 3788, 76th Illinois General Assembly (1970), §§ 8, 10, 11, 13, 27.

s See text at notes 131-49 infra.
} 
statewide standards and sometimes did not; it would have been a mistake to require them across the board, precluding consideration of the possibility that what was needed to avoid a serious problem in Chicago might be an utter waste of money somewhere else. More seriously, the original bill would expressly have forbidden the Board to consider cost in prescribing standards of air and water quality, which "as a minimum" would have been required to "ensure the elimination of health hazards and the enhancement of air [or water] quality." The amendments, sponsored of course by affected industry, wisely spared the Board from having to shut down a million-dollar plant if it found that the only way to avoid a single common cold.

The constitutionality of the basic delegation of rulemaking authority to the Pollution Control Board seems clear in light of the decision of the Illinois Supreme Court in Hill v. Relyea, ${ }^{9}$ which upheld a statute giving a hospital superintendent authority to discharge mental patients "as the welfare of such persons and of the community may require, under such rules and regulations as may be adopted by the Department." The General Assembly, the court held in Hill, may constitutionally "delegate to others the authority to do those things which the legislature might properly do, but cannot do as understandingly and advantageously" as can an administrative agency. "The constitution merely requires that intelligible standards be set to guide the agency charged with enforcement, . . . and the precision of the permissible standard must necessarily vary according to the nature of the ultimate objective and the problems involved." As the Board pointed out in rejecting constitutional objections in EPA v. Granite City Steel Co. ${ }^{10}$ the quasilegislative authority upheld in Hill was far broader and more unconfined than that of the Pollution Control Board:

Power to adopt regulations on air pollution ... is expressly limited both by the detailed and careful delineation of statutory purposes in sections 2 and 8 and by the explicit listing of factors relevant to the exercise of rulemaking judgment in section 27 . In addition, guided by the additional experience gained during seven years under the prior statute, the General Assembly added [in $\S 10]$ a detailed list of certain types of regulations that might be prescribed by the Board . . . . The Legisla-

\footnotetext{
? 34 Ill.2d 552, 555-56, 216 N.E.2d 795, 797 (1966).
}

10 1 P.C.B. 315, 316-18 (1971). 
ture could hardly have been more specific without adopting numerical standards itself. ${ }^{11}$

Thus it is not surprising that the Illinois courts have given short shrift to any argument that the Act contains unconstitutional delegations of legislative power. Several decisions, including one by the supreme court, have upheld Board regulations without adverting to any delegation problem; ${ }^{12}$ one in explicit dictum has flatly said the grant of authority to make water-pollution regulations is not an unconstitutional delegation..$^{13}$ Others have squarely rejected delegation arguments respecting the power to adopt permit requirements ${ }^{14}$ and the statutory prohibition of air pollution, ${ }^{15}$ both of which leave about as broad an area of judgment to the Board as do the basic rulemaking provisions.

Despite the general policy of leaving the content of substantive standards to the Board, the statute does contain a few outright prohibitions of its own. First, and most important, the statute makes it unlawful to discharge contaminants not only "so as to violate regulations or standards adopted by the Board," but also "so as to cause or tend to cause air [or water] pollution in Illinois."16 The logic behind these provisions was explained to the Senate Subcommittee considering the bill in this way:

We have been asked to eliminate the general prohibition against causing pollution, so that only violations of specific regulations can be punished. But there will always be a need for a catchall general nuisance provision, because no Board will be able to think of specific standards to govern every conceiva-

"Id. at 318.

12 Illinois Coal Operators Ass'n v. PCB, 59 Ill. 2d 305, 319 N.E.2d 782 (1974); Armstrong Chemcon, Inc. v. PCB, 18 Ill. App. 3d 753, 310 N.E.2d 648 (1st Dist. 1974); A.E. Staley Mfg. Co. v. EPA, 8 Ill. App. 3d 1018, 290 N.E.2d 892 (4th Dist. 1972).

${ }_{13}$ Meadowlark Farms, Inc. v. PCB, 17 Ill. App. 3d 851, 855-56, 308 N.E.2d 829, 832-33 (5th Dist. 1974). The only violation involved was a statutory one. The delegation question seems to have been discussed in response to the argument that the Board could not decide Meadowlark in quasi-judicial fashion because it had quasi-legislative powers as well.

" Southern Illinois Asphalt Co. v. EPA, 15 Ill. App. 3d 66, 78, 303 N.E.2d 606, 615 (5th Dist. 1973), aff'd on other grounds, 60 Ill.2d 204, 326 N.E.2d 406 (1975).

${ }^{15}$ Cobin v. PCB, 16 Ill. App. 3d 958, 970, 307 N.E.2d 191, 199 (5th Dist. 1974) (also rejecting a delegation argument against the more specific statutory ban on open burning). See also Bath, Inc. v. PCB, 10 Ill. App. 3d 507, 509, 294 N.E.2d 778, 780 (4th Dist. 1973) (rejecting a delegation attack on the questionable ground that section 49 of the Act, which preserved pre-existing regulations until modified by the new Board, "indicated legislative approval" of the challenged landfill rules).

is $\$ \S 9(\mathrm{a}), 12(\mathrm{a})$. See also $\$ 18$ (requiring custodians of public water supplies, even absent regulations, "to maintain the continuous operation and maintenance of water-supply facilities so that water shall be assuredly safe in quality, clean, adequate in quantity, and of satisfactory mineral character for ordinary domestic consumption."). 
ble kind of harmful emission. It would be possible to have the Board adopt a catchall regulation of its own, but there is no reason the General Assembly should leave this obvious issue to the Board. One thing we can be sure of is that no one should be allowed to cause a nuisance; there are prohibitions like the one under consideration in the present state statutes as to both air and water pollution, and they must be retained. ${ }^{17}$

Moreover, as the Board said, even the adoption of emission limitations for specific contaminants may not eliminate the need for such a provision, "for numerical limits only state what is acceptable in ordinary situations; under special circumstances of geography, meteorology, or configuration, emissions meeting the standards may cause a nuisance, and that the statute flatly forbids."18 In general the provisions governing enforcement of the statutory prohibitions of air and water pollution ${ }^{19}$ are intended to be flexible enough to permit the Board to determine applicable standards on the basis of the same competing considerations that govern its rulemaking power; the extent to which this intention was realized by the ultimate statutory language I shall explore in a later article.

But this approach was not carried through in the provisions dealing with solid-waste disposal or noise. Even the original bill contained no prohibition of "land pollution," and the Administration accepted an industry amendment omitting the bracketed word "or" from section 24: "No person shall emit . . . any noise that unreasonably interferes with the enjoyment of life or with any lawful business or activity, [or] so as to violate any regulation or standard adopted by the Board . . . " Apart from political compromise (possibly based on a sense that the new noise provisions were of secondary importance), the only evident argument for treating noise differently from air or water pollution is the relative novelty of noise control programs. But this cuts both ways: although the absence of numerical standards may pose greater risks of uncertainty to potential violators because of the scarcity of precedent, there is a correspondingly greater need for case-by-case development as a prelude to the formulation of intelligent standards.

17 Testimony of David P. Currie before Subcommittee of the Executive Committee of the Illinois Senate, on H.B. 3788 and Related Bills, May 25, 1970, pp. 9-10. The Mlinois supreme court has confirmed that the statutory prohibitions may be enforced directly without the adoption of Board regulations. Mystik Tape v. PCB, 60 Ill. 2d 330, 335, 328 N.E.2d 5, 8 (1975).

${ }^{18}$ In re Emission Standards, 4 P.C.B. 298, 301 (1972). Section 49(e) explicitly making compliance with the regulations only a "prima facie" defense, that is, one subject to rebuttal, to a charge of violating the statute itself).

19 $\S \S 3(b),(n), 31(c), 33(c), 35$. 
For better or for worse (and I incline toward the latter characterization), the omission of a statutory ban on unreasonable noise left the State powerless to abate even the most unjustifiable noise for the three years before the Board adopted its first relevant regulations. Those regulations, moreover, applied only to certain types of noise sources, excluding, for example, important categories such as construction and transportation. To foreclose the possibility that more years of information gathering would have to precede any enforcement against such sources, the Board promulgated its own general nuisance regulation: "[n]o person shall cause or allow the emission of sound . . . so as to cause noise pollution," which was defined as "the emission of sound that unreasonably interferes with the enjoyment of life or with any lawful business or activity."20 These provisions were upheld in Illinois Coal Operators Association $v$. $P C B^{21}$ against an inept argument that by going on to prohibit emissions that "violate any provision of [these regulations] or the Illinois Environmental Protection Act," the rule attempted to regulate emissions that did not cause unreasonable interference.

The crucial argument appears not to have been made: that the General Assembly, by refusing to adopt a nuisance provision for noise, had determined that the Board should proceed only by adopting specific numerical regulations. For the prospective defendant is placed in quite the same uncertainty if the nuisance provision is promulgated by the Board instead of by the legislature; and section 25 , without close parallel in the air or water sections, provides that the Board "shall . . . categorize the types and sources of noise emissions that unreasonably interfere" and prescribe for each "the maximum permissible limits." The statutory language, however, does not compel this conclusion. Although section 25 does not expressly tie noise regulations to the accomplishment of the purposes of the statute, as do the comparable air and water provisions, that connection seems implicit in the juxtaposition of a purpose "to prevent noise which creates a public nuisance" with the bare authority to adopt regulations "prescribing limitations on noise emissions beyond the boundaries of the property of any person." 22 That the Board is to establish more specific limits by category does not necessarily mean that it may do no more under the facially broader grant of authority just quoted. The legislative history is at least equally consistent with the conclusion that the General Assembly meant to

${ }^{20}$ PCB Regs., ch. 8, Rules 102, 101(j).

21 59 Ill. 2 d 305, 309-10, 319 N.E.2d 782, 784-85 (1974).

$22 \S 23$. 
leave it to the Board, in view of its superior experience, to weigh the pros and cons of a general ban on unreasonable noise. ${ }^{23}$ In light of the Senate testimony that a general nuisance provision would always be necessary "because no Board will be able to think of specific standards to govern every conceivable kind of harmful emission," ${ }^{24}$ it is impossible to reconcile the putative absence of authority to adopt such a provision with the express statutory purpose "to prevent noise which creates a public nuisance." The regulation preventing unreasonable noise should be upheld..$^{25}$

The statutory prohibitions were not wholly confined to general nuisance provisions leaving the balance of benefits and costs to the expert Board. When one thinks a practice inexcusable, the urge is strong to outlaw it by statute rather than to risk inaction or error by the Board. So it was, for example, with open burning. In this day of sophisticated incinerators and sanitary landfills it seemed primitive and unnecessary to produce pillars of smoke by burning refuse in the open. Thus section 9(c) flatly forbids the "open burning of refuse," subject only to Board authority to make exceptions by regulation if it finds that "no harm will result from such burning" or that "any alternative method of disposing of such refuse would create a safety hazard so extreme as to justify the pollution" from open burning. The Board was flooded with requests for hardship variances from this provision; closer investigation showed that open

23 Indeed I had discussed such a possibility before the Senate Subcommittee. See text at notes 16-17 supra.

21 Id.

${ }_{25}$ The converse argument might be made that, because section 24 makes unlawful only unreasonable noise that violates regulations, and because section 23 of the bill was amended so that the purpose was to prevent not "excessive" noise but that which "creates a public nuisance," the only regulation the Board may adopt is a general nuisance provision. That such an interpretation would make the entire noise section little more than a restatement of existing common law argues it was not intended; that section 25 expressly directs the Board to set "maximum permissible limits" of unreasonable noise for various categories of emission sources clearly indicates that numerical definitions of unreasonable noise were contemplated. That the standards may prohibit only emissions that "unreasonably interfere" with activities seems merely to make explicit the balancing of costs and benefits that is required for all regulations by section 27; the reference to "public nuisance" should be taken merely to stress that costs as well as benefits must be taken into account, not to limit the Board to idly prohibiting what is already forbidden.

Nor should section 24 be read to require that a complainant demonstrate that an emission in violation of a regulation also causes unreasonable interference in his particular case. So to hold would defeat the very point of adopting regulations, which establish, short of proof that compliance would impose unreasonable hardship on a given individual, that the proscribed emissions are unreasonable.

The noise provisions were badly butchered in the legislative process and are seriously in need of clarification. 
burning encompassed far more than the prototype case of striking the match to a pile of garbage. At length the Board adopted regulations permitting under appropriate circumstances such activities as campfires, leaf-burning by rural homeowners, and fires to train firemen, finding that countervailing costs or needs outweighed the "relatively little harm" caused. ${ }^{26}$ The statute, however, requires in all these cases a finding that no harm will result, not merely that any resulting harm is justified; only by a less than faithful paraphrase was the Board able to avoid the burden of dealing with all such cases on an individual basis. I think this humble example underlines the dangers of making final determinations of specific and complex issues in the statute itself. ${ }^{27}$

${ }^{26}$ In re Open Burning Regulations, 2 P.C.B. 373 (1971).

${ }^{27}$ Section 9 (c) also prohibits the conducting of salvage operations by open burning and the burning of refuse "in any chamber not specifically designed for the purpose and approved by the Agency pursuant to regulations adopted by the Board . . . ." The latter provision not only outlaws the once widespread and offensive practice of burning garbage in furnaces, but also can be read to require permits for all incinerators, contrary to the basic principle (e.g., $\$ \$ 9(b), 12(b))$ leaving it to the Board to determine which types of pollution sources are significant enough to justify the administrative costs of processing permit applications. The Board has in fact exempted classes of "numerous small sources" such as automobiles and home furnaces from its permit requirements, though not from substantive limitations, "because the burden of processing permits in these cases would not be justified by the benefits," PCB Regs., ch. 2, Rule 103(i); In re Emission Standards, 4 P.C.B. 298, 304 (1972), but a permit is required for "any incinerator," Rule 103(i)(8). Similarly, section 12(c) flatly requires a construction permit for "any sewer or sewage treatment facility or any new outlet for contaminants into the waters of this State," and for any increase in an existing discharge. This language seems to invalidate the Board's reasonable exclusions for storm sewers carrying only land runoff and for sewers and treatment works "intended to serve a single building and eventually transport, treat, or discharge the sewage of 15 or less persons," PCB Regs., ch. 3, Rule 901(b)(1), (2). Further, section 15, perhaps less controversially, requires a permit for construction of any new or enlarged facility for public water supply, while section 21(e) requires permits to collect or dispose of the refuse of others after adoption of substantive Board regulations.

Section 21 also outlaws the open dumping of garbage, the deposit of any refuse on public property except in an approved sanitary landfill, and the disposition of refuse "except at a site or facility which meets the requirements of this Act and of regulations thereunder." The central purpose of the last provision was to keep people from dumping outside of recognized dump sites, but read literally it could make every user of a landfill responsible for the fill owner's smallest infraction of the housekeeping rules. See EPA v. City of Waukegan, 3 P.C.B. 301,306 (1971) (alternative holding), holding that those in the dumping business must ascertain whether or not the site owner has a permit, lest they have "carte blanche . . . to dump anywhere they wish and say 'I didn't know.'" Section 12(d) makes it unlawful to "deposit any contaminants upon the land in such place and manner so as to create a water pollution hazard." And section 9(e), adopted after the Board had adopted more comprehensive and more stringent asbestos standards, preserves the Board's power to regulate in that realm but forbids "the spraying of loose asbestos for the purpose of fireproofing or insulating any building or building materials or other constructions" and any other use of asbestos "in such unconfined manner as to permit asbestos fibers or particles to pollute the air." Since air pollution was already forbidden by section $9(a)$, the last clause appears to add nothing but 
On the other side of the coin, interest groups were able to persuade the General Assembly to deny the Board any authority to adopt certain classes of regulations that might have been found to serve the statute's overall purpose of preventing unjustifiable pollution. First, section 13(f) clumsily provides, contrary to the statutory finding that various pollution problems "must be dealt with as a unified whole," 28 that any Board standards "regarding the sale, offer, or use of any pesticide" shall be adopted "only in accordance with" an earlier statute requiring the prior approval of an agriculture-dominated Interagency Committee. ${ }^{29}$ Presumably this limitation on the Board's rulemaking power does not render the statutory ban on water pollution ${ }^{30}$ inapplicable to pesticides, but whether the Board may adopt effluent standards for pesticides is less clear. On the one hand, such standards certainly would affect the use of pesticide, because they would require measures to reduce runoff to the waters. On the other, the statute provides separately for effluent standards, and for conditions on sale or use of a product, ${ }^{31}$ and legislative history shows the two categories were viewed as distinct. ${ }^{32}$ The pesticide proviso appears in a paragraph authorizing the latter type of regulation; this separation argues that the exclusion from the Board's authority extends only to regulations directed against the product itself.

Second, the original bill, in order to promote section 20 's express purpose of "encouraging and effecting the re-cycling and reuse of waste materials," would have authorized the Board to adopt "standards, conditions, and prohibitions" regarding the sale or use of any article (specifically including bottles and other containers) determined to create "an unreasonable burden of disposal." 33 This was designed to enable the Board "to deal with such problems as non-returnable bottles." 34 It was omitted after vehement substan-

verbiage; and if asbestos poisoning is so clearly unjustifiable as to require statutory security against the possible repeal of regulations just promulgated by the Board, I see no reason for limiting the prohibition to spraying that is done for fireproofing or insulation purposes.

${ }_{23} \S 2$ (a)(iii).

29 Ill. REv. STAT. ch. 5, § 273.1 (1973).

${ }^{30} \S 12(\mathrm{a})$.

${ }^{31} \S \S 10(\mathrm{~b}),(\mathrm{d}), 13(\mathrm{~b}),(\mathrm{f})$. Similarly, there are separate prohibitions against violating discharge standards and against sale or use of proscribed products. $\$ \S 9(a),(d), 12(a),(e)$.

${ }^{32}$ Governor Ogilvie said in recommending the bill to the legislature that these provisions empowering the Board "to regulate or prohibit the sale or use of fuels and other articles that create a danger of pollution" were intended "to clarify the power to adopt regulations [for example] limiting the sulfur content of fossil fuels" directly, as an alternative to the adoption of emission standards. R. OgIlvie, Special Message on the Environment 5-6 (April 23, 1970).

${ }^{33}$ H.B. 3788, 76th Illinois General Assembly (1970), § 22(b).

34 R. OGILvIE, supra note 32 , at 6. 
tive objections from industry, but no express prohibition on such regulations was inserted, and arguably the necessary authority is conferred by section 22's general power to adopt regulations "to promote the purposes of this Title," which, as indicated above, plainly include recycling. Such a reading would mean that the omission of specific authorizing language merely left it to the Board and to the courts to determine whether prohibitions on the sale of articles posing a disposal problem served the statutory purpose. But so to hold would make industry's hard-fought legislative victory a hollow one, and such was not the Administration's understanding of the consequence of the omission: I testified before the Senate subcommittee that one of the "most significant changes" during the legislative process was the "narrowing of the proposed novel power to adopt regulations promoting the recycling of solid wastes." 35

Moreover, to uphold the Board's power to forbid the sale of items creating disposal problems under section 24 would ignore the legislative adoption, at industry's suggestion, of a more circumscribed authorization clearly intended as a compromise. Section 6 requires the establishment of a Solid Waste Management Task Force within the Institute for Environmental Quality with authority, among other things, "to expedite development of systems for the re-cycling and re-use of refuse and solid waste materials" and to make recommendations on subjects within its competence for submission to the Board. The Board in turn is directed to "make rules and regulations on these subjects based upon such recommendations." The extent of the section 6 rulemaking power is discussed two paragraphs below, but at the very least it seems plain that the legislative compromise was designed to make a Task Force report a prerequisite to the imposition of conditions on the sale of items deemed to create an unreasonable disposal problem. ${ }^{36}$

Finally, the original bill included novel provisions that would have authorized the Board to set money charges for the emission of contaminants or for the use of articles creating an unreasonable

${ }^{35}$ Testimony of David P. Currie before Senate Subcommittee on H.B. 3788, May 1970, p. 2. Still more explicit was my contemporaneous press release:

The proposed power to bar or limit the sale of non-returnable bottles and other substances which cause an unreasonable problem of disposal was eliminated. This proposal was one of the chief sources of industry objections, and it admittedly is an untried economic weapon which could be misused.

We therefore accepted an amendment allowing limited regulation after a research study of waste recycling, which is about all the power we know how to use today. Illinois News, \# 966-70, May 29, 1970, at 7.

* The Board so held, In re Non-Returnable Cans \& Bottles, 1 P.C.B. 305 (1971). 
problem of disposal. ${ }^{37}$ Such charges, it was argued, "serve two purposes: They require people who use public resources for their own profit to pay for them, and they create an economic incentive for producers to reduce pollution." ${ }^{\prime 38}$ Regulations of this type are very popular with economists, who view them as making the market work to control pollution, ${ }^{39}$ but they are far from self-defining. To internalize the harm done by pollution, a charge should reflect the marginal damage done by each unit of pollutant emitted. But the money value of such detriments as health risks and the impairment of scenery has proved elusive even to economists. ${ }^{40}$ The problem is exacerbated by the fact that the damage done by a unit of a given contaminant varies sharply according to a whole host of factors: the number of additional units of the same or of other contaminants present; the quantity of the receiving medium effectively available for dilution; ${ }^{41}$ the type, number, proximity, sensitivity, and value of pollutable objects within the affected area; and the self-defensive measures that are taken or ought to be taken by potential victims. In any event, industry opposition was so violent that the statute as enacted not only omitted affirmative authorization for money charges but (in section 27) flatly forbade them: "[n]o charge shall be established or assessed by the Board or Agency against any person for emission of air contaminants from any source, for discharge of water contaminants from any source, for the sale, offer or use of any article, or for disposal of any refuse."

Notwithstanding the deliberate omission of authority to prohibit or condition the sale of articles posing disposal problems and the express prohibition of regulations setting money charges, the Institute's task force proposed a regulation requiring the collection of a refundable deposit on the sale of certain beverages in cans or bottles. The Board upheld its authority to adopt such a regulation and ordered hearings, reading section 6 as a compromise whose sole effect was to delay the adoption of such conditions until completion of an expert study. The argument that a deposit was a "money charge" expressly forbidden by section 27 was not discussed. ${ }^{42} \mathrm{~A}$

${ }^{37}$ H.B. 3788, 76th Illinois General Assembly (1970), §§ 10(e), 13(g), 22(b).

${ }^{38}$ Testimony of David P. Currie before Subcommittee of Executive Committee of the Illinois Senate, on H.B. 3788 and Related Bills, May 25, 1970, p. 9.

${ }^{39}$ See, e.g., A. Kneese \& B. Bower, Managing Water Quality: Economics, Technology, INSTITUTIONS (1968).

so See, e.g., Ridker, Strategies for Measuring the Cost of Air Pollution, in The Economics of Air Pollution 87 ( $\mathrm{H}$. Wolozin ed. 1966), attempting to measure harm through discrepancies in land values.

"For example, the size of a stream or the strength of the wind.

${ }^{12}$ In re Beverage Container Regulations, 3 P.C.B. 471 (1972). 
trial-court injunction against conducting the hearings was set aside on appeal on the ground that the attack on the Board's jurisdiction was premature since no regulations had yet been adopted..$^{43}$

The question of authority is a close one. On the one hand, a deposit is a "charge" in the sense that it is a required transfer of money. On the other, the purchaser will get it back when he returns the bottle; unlike a naked tax, the deposit is not designed to make the purchaser poorer in order to discourage his purchase. It could plausibly be argued that the deposit regulation in effect imposes a money charge for failure to return the container, but, unlike the ordinary charge contemplated by the section 27 prohibition, the deposit is paid to the seller and not to the State. To read section 27 as forbidding deposits as well as outright charges would appear to leave very little of section 6's clear authority to adopt regulations to "expedite development of systems for . . . recycling." No doubt such an emasculation would comport with the industry desires behind the amendments, but the statute's language does not compel it. I would hope the courts will find sufficient distinction between returnable deposits and outright charges to avoid holding that the legislature completely failed to provide authority to accomplish the clear statutory purpose of "encouraging and effecting the re-cycling and re-use of waste materials." 44

In sum, with a few relatively minor exceptions, the plan of the statute is to place principal reliance upon regulations adopted by the Board upon consideration of costs and benefits, with supplementary statutory nuisance provisions intended to allow case-bycase enforcement on the basis of similar considerations in situations not fully provided for by specific regulations.

\section{Procedure}

Section 26 requires the Board, in adopting rules governing its own procedures, to give public notice of its intention and to accept written comments. When the proposed regulation is "substantive," section 28 further requires "a public hearing," attended personally by at least one Board member, at which "any person" is given "a reasonable opportunity to be heard." The contrast with section 26 , and the explicit provisions governing the time and place of the hearing, preclude any conclusion that the "hearing" requirement could be satisfied by mere notice and opportunity for written com-

13 Gromer Supermarket, Inc. v. PCB, 6 Ill. App. 3d 1036, 287 N.E.2d 1 (1st Dist. 1972).

4 $\$ 20$. 
ment; ${ }^{45}$ at a minimum, section 28 contemplates the opportunity to present one's views orally.

Similar provisions were found in the prior Illinois air pollution statute, ${ }^{46}$ though eschewed by the federal Administrative Procedure Act in the absence of specific statutory requirements. ${ }^{47}$ Even if, as often happened under the earlier Illinois provisions, such a hearing consisted solely of the reading aloud of statements that were also submitted in writing, it would have symbolic value in giving the citizen a greater sense of participation by the opportunity to speak to the rulemaker face to face. Moreover, a public hearing may satisfy a fear that what is presented in writing may not be read or given appropriate attention by busy members of the Board. On the other hand, requiring a member to sit through a hearing does not assure either that he will listen carefully or that he will pass the information he obtains on to his colleagues. Were the sole benefits of public hearings those already mentioned, I would have doubts that the inefficiency of reading statements aloud was justifiable.

The real utility of a public hearing lies in the opportunity it can afford for exploring the weaknesses of opposing positions. The essence of a meaningful opportunity to comment upon proposed regulations, as the District of Columbia Circuit held in Portland Cement Association $v$. Ruckelshaus ${ }^{48}$ is to know the basis upon which the rule is proposed. Accordingly, section 28 of the Illinois statute requires the Board in proposing a regulation to make available not only the text of the proposals but also "summaries of the reasons supporting their adoption." Moreover, the Board has made clear that it expects the proponent of a regulation to make an affirmative case for its adoption at the public hearings; indeed, it has based its rulemaking decisions solely upon the public record in order to avoid the risk of error attendant upon reliance on undisclosed and unrebutted information..$^{9}$ One appellate court, taking the Board at its

${ }^{45}$ As was surprisingly held with respect to an ICC rulemaking provision in United States v. Florida East Coast Ry., 410 U.S. 224 (1973). See Williams, "Hybrid Rulemaking" under the Administrative Procedure Act: A Legal and Empirical Analysis, 42 U. CHI. L. REv. 401, 414 (1975).

${ }^{48}$ Ilz. Rev. Stat. ch. 111, § 240.7 (1967).

${ }^{47} 5$ U.S.C. $\$ 553$ (1970).

18486 F.2d 375, 393-94 (D.C. Cir. 1973).

49 This practice has been facilitated by the creation of a separate Institute with a statutory mandate to "give expert guidance to the Agency and to the Board in the formulation of regulations" ( $(6)$, and by the consequent limitation of the Board's own staff in order to reduce duplication. This separation of personnel deliberately makes the Board largely dependent upon others to propose regulations and creates a strong incentive for the proponent to reveal the basis for its proposal in order to persuade the Board. As the Board itself observed 
word, has adjudicated the validity of its regulations on the basis of the administrative record. ${ }^{50}$

Public hearings facilitate public awareness of the justification for proposed regulations, but they are not the only means to that end. The essence of the opportunity to know could be assured by an expansive interpretation of the "summaries" of supporting reasons required by section 28 along the lines of the Portland Cement case, ${ }^{51}$ coupled with the existing provision that all submissions to the Board be "open to public inspection." 52 That a decision must be based upon a record does not necessarily mean the record must be an oral one. But the final and possibly overriding advantage of an oral hearing is the enhanced opportunity it affords for probing the soundness of presentations, whether for or against a proposal, by questioning.

Questions may of course be posed and answered in writing. ${ }^{53}$ This practice, however, may be quite time-consuming; if replies are evasive or incomplete or suggest new lines of inquiry, a new round of questions must be written and answered. Consequently, the Board's procedural regulations authorize cross-examination by Board members or Board counsel, by the proponent of a regulation, and by the Agency, Institute, and Attorney General. ${ }^{54}$ Although cross-examination by affected members of the public is inadequately left to the "discretion" of the hearing officer, in practice everyone has been permitted to cross-examine. I have no basis for quarreling with those observers who have found trial-type rulemaking procedures unduly burdensome for the federal Food and Drug Administration, ${ }^{55}$ but I found that rulemaking on the record of hearings in which full cross-examination was permitted worked extremely well for the Pollution Control Board. The subject is one in which there are numerous crucial issues turning on narrow technical findings such as the extent of damage to fish from a given exposure

in encouraging the increasing dominance of the other agencies in proposing regulations, "this Board can function best on the basis of concrete proposals . . . made and supported by another agency such as the EPA." In re Emission Standards, 4 P.C.B. 298, 300 (1972).

so Commonwealth Edison Co. v. PCB, 25 Ill. App. 3d 271, 271, 281, 323 N.E.2d 84, 90, 94 (1st Dist. 1974).

st "Information should generally be disclosed as to the basis of a proposed rule at the time of issuance." Portland Cement Ass'n v. Ruckelshaus, 486 F.2d 375, 393-94 (D.C. Cir. 1973).

$52 \S 28$.

${ }^{53}$ Cf. FEd. R. Civ. P. 33 (discovery by interrogatories).

st PCB Regs., ch. 1, Rule 208.

${ }^{5 s}$ See Hamilton, Procedures for the Adoption of Rules of General Applicability: The Need for Procedural Innovation in Administrative Rulemaking, 60 CALIF. L. REv. 1276 (1972). 
to heat and the degree of emission reduction achievable from use of available control equipment. The Board found cross-examination of considerable value on such issues, and in my experience the privilege was not so abused or overused as to make the burdens outweigh the benefits. I do think the value of cross-examination would be enhanced (at the cost of depriving the Board of the views of those who missed the deadline) by greater use of the authority "to require prior submission of expert testimony and exhibits in writing," but the adverse publicity generated by telling people they cannot be heard-especially since those most likely to be trapped by such a rule are the unorganized general public-makes any such course improbable so long as oral presentations are permitted. Perhaps a more promising reform, although one that would require an amendment to the statute, would be to dispense with oral reading of direct testimony and to conduct a hearing only for the purpose of crossexamination on the basis of prior written submissions..$^{57}$

That the statute requires the Board to base regulations upon an affirmative showing in the record, as it has done, is less than clear, however. On its face, section 28 requires only the typical opportunity for oral public comment. The clause permitting a proposal to be revised only "in response to suggestions made at the hearings" is adequately explained as assuring fair notice of proposed revisions and does not imply that a public case must be made in support of the original proposal too. The strongest argument that the Act requires regulations to be justifiable by the record can be drawn from sections 29 and 41, which provide for review of Board regulations directly in the appellate court. Since it would not be practical for an appellate court to take new evidence, ${ }^{58}$ a reasonable inference is that review is to be based upon the record compiled by the Board. This inference is not inescapable, however, since respectable authority exists that the "legislative" facts that determine the validity of regulations on their face may be presented by such nonevidentiary means as the Brandeis brief, ${ }^{59}$ and since one appellate court has held that the exclusive procedure for attacking a regulation on the basis of facts respecting its application to a particular case is to seek a variance from the Board. ${ }^{60}$ Such important safe-

${ }^{36}$ PCB Regs., ch. 1, Rule 206(a)(1).

${ }^{37}$ See Catterall, The Procedures of the Virginia State Corporation Commission, 38 J. AM. JuD. Soc'y 61 (1954).

${ }^{58}$ See generally Currie \& Goodman, Judicial Review of Federal Administrative Action: Quest for the Optimum Forum, 75 CoLum. L. Rev. 1, 39-54 (1975).

39 See K. Davis, Administrative Law Text 160-71 (3d ed. 1972).

${ }^{80}$ Commonwealth Edison Co. v. PCB, 25 Ill. App. 3d 271, 281, 323 N.E.2d 84, 90 (1st Dist. 1974). 
guards as the opportunity to know and to question the basis of a proposed regulation ought not to be left to the grace of the Board; it would be better if the statute plainly required regulations to be based upon the record, with some right to pose oral or at least written questions.

The last paragraph of section 28 , quoted in part in the preceding paragraph, allows the Board to make revisions to a proposed regulation in response to suggestions received, without holding another hearing. Without such a provision, the hearing process might become interminable. Yet sweeping revisions without opportunity for comment, even if made in response to suggestions offered at the hearing, might undermine the purpose of the requirements of notice and hearing. In an effort to reconcile the competing goals of public participation and of administrability, the Board's rules require publication of post-hearing revisions and a brief opportunity for written comment. ${ }^{61}$ It is possible to argue that comments so received must not be the basis of further revisions because they are not "suggestions made at the hearing," or that the regulation itself requires still another round of notice and comment if such further revisions are made. But the purpose of opportunity to comment is met by construing "hearing" in this context to include written submissions, which the statute explicitly treats as part of the rulemaking record and opens to inspection. And the federal courts have sensibly rejected the argument that a comparable notice-and-comment provision requires a new chance to comment every time a proposal is revised: "A contrary rule would lead to the absurdity that . . . the agency can learn from the comments on its proposals only at the peril of starting a new procedural round of commentary." 62 The Board has promised a second round following the hearing; the principle of diminishing returns and the need for finality suggest it should be allowed some discretion in determining the need for a third round.

\section{Mechanisms for Judicial Review}

Judicial review of the validity of a regulation can normally be had by way of defense to an enforcement proceeding for violating it; but as the sole avenue of obtaining judicial review this method

" PCB Regs., ch. 1, Rule 211.

12 International Harvester Co. v. Ruckelshaus, 478 F.2d 615, 632 \& n.51 (D.C. Cir. 1973). See also South Terminal Corp. v. EPA, 504 F.2d 646, 658-59 (1st Cir. 1974), repeating favorably the language quoted in the text and adding that the final regulation was a "logical outgrowth of the hearing" for which sufficient notice had been given. 
would be inadequate, because it would require one honestly in doubt as to the law to risk serious penalties in order to test that doubt. ${ }^{63}$ Consequently, section 29 of the Environmental Protection Act entitles "any person adversely affected or threatened" by a Board regulation to "obtain a determination of the validity or application of such rule or regulation by petition for review under Section 41 ." The latter section authorizes review in the appellate court ${ }^{64}$ (but otherwise pursuant to the Administrative Review Act) upon petition by "any party adversely affected by a final order or determination of the Board" and adds that "review of any rule or regulation . . . shall not be limited by this section but may also be had as provided in Section 29." This final proviso is largely meaningless, since section 29 basically refers the reader back to section 41 . The explanation is historical. In the original bill, section 29 provided a distinct remedy, a petition to the Board to determine the scope or validity of its own regulation. ${ }^{65}$ The present significance of the reference back to section 29 is that it enlarges the class of eligible challengers to a regulation: not only those who were "parties" to the rulemaking proceeding, whatever that may mean, but anyone adversely affected or threatened by the regulation may file a petition for judicial review. ${ }^{66}$

The express provision in section 29 that section 41 allows review of regulations appears to override any contrary argument based upon the narrower definition of "decision" in the Administrative Review Act, ${ }^{67}$ or upon the position that direct appellate court review is appropriate only when the administrative decision is required to be based upon a record; $;^{68}$ the courts have not questioned the author-

${ }^{63}$ See Steffel v. Thompson, 415 U.S. 452 (1974).

64 "The further proviso "and not in the Circuit Court" makes clear that the jurisdiction of the appellate court is exclusive.

${ }^{65}$ One reason for omitting this provision may have been the probable futility of asking the Board to strike down a rule it had just adopted, presumably after considering arguments against its validity.

"Precisely who qualifies as "adversely affected or threatened" has yet to be determined. Compare the variety of views as to the meaning of similar words in the federal Administrative Procedure Act, discussed in D. Currie, Federal Courts ch. $1, \S 3$ (2d ed. 1975).

${ }^{67}$ ILl. Rev. Stat. ch. 110, § 264:

The term "administrative decision" or "decision" does not mean or include rules, regulations, standards, or statements of policy of general application issued by an administrative agency to implement, interpret, or make specific the legislation enforced or administered by it unless such a rule, regulation, standard or statement of policy is involved in a proceeding before the agency and its applicability or validity is in issue in such a proceeding, nor does it mean or include regulations concerning the internal management of the agency not affecting private rights or interests.

See, e.g., United Gas Pipe Line Co. v. FPC, 181 F.2d 796 (D.C. Cir. 1950), holding for this reason that regulations are not "orders" subject to direct appellate review under the 
ity for direct review despite the clumsiness of the drafting. ${ }^{69}$ But elimination of the Board remedy for determining the applicability of a regulation seems to have created a gap in the statute. For section 41 speaks only of "judicial review" of what the Board has done, and "review" implies a determination of the correctness, not of the meaning, of Board action. Indeed, it would be questionable, in terms both of the value of administrative expertise ${ }^{70}$ and of the awkwardness of holding evidentiary trials at the appellate level to hold that the statute authorizes an appellate court to render an interpretation of a regulation without first getting the views of the Board. Uncertainty as to the meaning of a regulation can often be clarified by filing a petition for variance; if there is no need for a variance because the regulation is inapplicable, the Board can say so in its opinion. ${ }^{71}$ The same considerations-utilizing the experience of the specialized Board, and the awkwardness of conducting a trial at the appellate level-support the decision in Commonwealth Edison Co. v. EPA ${ }^{72}$ that the avenue for challenging the validity of a regulation as applied to particular facts is to petition for variance, not to seek direct review under sections 29 and 41 .

On two occasions, persons subject to proposed Board regulations have attempted to circumvent the statutory scheme by filing challenges in the trial courts before adoption of the regulations. In Gromer Supermarket, Inc. v. $P C B,{ }^{73}$ the Board had scheduled hearings on a proposed regulation that would require the collection of a deposit on certain beverage containers and had written an interlocutory opinion rejecting the argument that the statute gave it no such authority. ${ }^{74}$ In Roth-Adam Fuel Co. v. PCB ${ }^{75}$ the Board after extensive hearings had published a "proposed final draft" of a regulation

Federal Power Act. Even in the absence of specific statutory language making regulations directly reviewable, the United Gas Pipe view is declining in the face of the courts' increasing tendency to require the equivalent of a rulemaking record. See Currie \& Goodman, supra note 58, at 39-54. Since the Board in fact does base its regulations on the rulemaking record, direct review makes eminent sense by eliminating the delays incident to an unnecessary trial court. See id.

" See, e.g., Illinois Coal Operators Ass'n v. PCB, 59 Ill. 2d 305, 319 N.E.2d 782, 783-84 (1974), noting that because jurisdiction had not been questioned it need not be discussed; Commonwealth Edison Co. v. PCB, 25 Ill. App. 3d 271, 275, 323 N.E.2d 84, 86 (1st Dist. 1974).

30 The principle of reliance on administrative expertise, however, is compromised to some degree by the clear statutory authority for enforcement complaints to be filed in court as well as with the Board. See People v. Janson, 57 Ill. 2d 451, 312 N.E.2d 620 (1974).

"Cf. North Shore Sanitary Dist. v. EPA, 6 P.C.B. 57 (1972) (reviewing denial of permit).

7225 Ill. App. 3d 271, 281, 323 N.E.2d 84, 90 (1st Dist. 1974).

736 Ill. App. 3d 1036, 287 N.E.2d 1 (1st Dist. 1972).

7 See text and notes at notes 29-35.

7510 Ill. App. 3d 756, 295 N.E.2d 321 (1st Dist. 1973). 
effectively preventing the use of coal for residential heating in the Chicago area and had solicited additional written comments. In each case the circuit court took jurisdiction over the Board's objection and enjoined further proceedings on the ground that the proposed rule would be invalid. In each case the appellate court reversed, holding the controversy not yet ripe for adjudication:

$[N]$ o person can predict the future course of action which the Board will take and whether or not it will, in fact, adopt the recommended regulation in any form . . . . No loss has been suffered by any of plaintiffs in any of their pertinent activities and no such loss is imminent. ${ }^{76}$

At its worst, pre-adoption review of proposed regulations would not only require the courts to decide issues that might later be mooted by the Board's decision not to adopt; it would also run counter to the statutory purpose of avoiding expensive and timeconsuming trial court proceedings, split judicial review into two or more separate proceedings, and deprive the reviewing court of the opinion of the Board upon matters within its specialized knowledge. Pre-adoption review thus would tend to affront the requirement that administrative remedies be exhausted ${ }^{77}$ as well as the general requirement of a ripe controversy.

The extent to which pre-adoption review would offend the above policies, however, varies from case to case, as does the countervailing need for immediate judicial intervention. It might have been significant in Gromer, for example, that the Board had already expressed its views on the statutory authority issue under attack in the courts; that, since hearings had not yet begun, postponing judicial review would remit the parties to a series of administrative proceedings that might prove both protracted and unnecessary; and that there might be insufficient time between final Board action and the date of required compliance both to complete judicial review and to prepare for compliance. At the time the trial court acted in Roth, on the other hand, the Board had not yet issued its opinion

${ }^{76}$ Roth-Adam Fuel Co. v. PCB, 10 Ill. App. 3d at 757, 295 N.E.2d at 322-23, paraphrasing Gromer Supermarket, Inc. v. PCB, 6 Ill. App. 3d at 1043, 287 N.E.2d at 7. This accords with federal decisions on the subject. E.g., Lever Bros. Co. v. FTC, 325 F. Supp. 371 (D. Me. 1971) (attack on proposed regulation unripe); Toilet Goods Ass'n v. Gardner, 387 U.S. 158 (1967) (attack on adopted regulation unripe where not self-executing). See also General Electric Co. v. Illinois, \# 71C2032 (N.D. Ill., Dec. 3, 1971) (refusing on grounds of prematurity to enjoin a permit proceeding despite the argument that federal law deprived the Pollution Control Board of authority to regulate radioactive emissions from nuclear fuel plants).

"See Myers v. Bethlehem Shipbuilding Corp., 303 U.S. 41 (1938). 
on the merits of the proposed regulation, which depended upon a consideration of costs and benefits that might have been highly relevant to the judicial question whether there was a taking without compensation. Moreover, since hearings had already been completed, there was no reașon to expect an extended or costly delay before final Board action made it possible for the appellate court to conduct an orderly direct review of the Board's opinion and record.

Yet even in Gromer the theory that an early review would be more efficient and would remove the plaintiff's uncertainty depended on the assumption that the jurisdictional challenge would prevail; otherwise there might have to be a second round of judicial review to determine additional issues raised by details of the final regulation. When, as in Gromer, the Board has already ruled on the objection pressed in court, the issue of early judicial interference is not unlike that of interlocutory appeal from a trial court; in general the undesirability of piecemeal appeals argues against intervention, in the absence of irreparable injury exceeding the cost of completing the challenged proceeding. ${ }^{78}$ This is especially true when, as here, the statute expressly places reviewing jurisdiction in the appellate court in order to sidestep the costs and delays of trial-court proceedings and explictly limits review to "final" Board orders and determinations. Indeed a strong argument can be made that the requirement of "final" Board action precludes earlier judicial action in every case. Illinois decisions allowing actions to enjoin enforcement proceedings before the Board under limited circumstances ${ }^{79}$ are not consistent with this interpretation. Review in such cases perhaps depends upon a flexible calculus such as that of Professor Davis, who has identified three important variables in determining whether administrative remedies must be exhausted: "extent of injury from pursuit of administrative remedy, degree of apparent clarity or doubt about administrative jurisdiction, and involvement of specialized administrative understanding in the question of jurisdiction." ${ }^{80}$ Yet the threat of "injury" is more remote when the pro-

${ }^{7 \pi}$ On interlocutory appeals see generally D. Currie, Federal Courts, ch. $2, \S 3$ (2d ed. 1975).

" City of Chicago v. PCB, 59 Ill. 2d 484, 322 N.E.2d 11 (1974), and W.F. Hall Printing Co. v. EPA, 16 Ill. App. 3d 864, 306 N.E.2d 595 (1st Dist. 1973), reaching the merits of actions to enjoin enforcement hearings before the Board-on the respective grounds that the operations of home-rule units were exempt and that the statute was unconstitutional-despite arguments that administrative remedies should first be exhausted. It is clear that both courts felt the questions at issue were not ones upon which the Board's expertise would be of much value.

* K. Davis, Administrative Law Text 387 (1972). 
ceeding sought to be enjoined is one looking toward adopting rather than enforcing a rule; indeed, in the former case there is arguably no adversary at all and hence no justiciable controversy until the regulation is adopted.

A further question concerning judicial review is whether defense to an enforcement proceeding, the normal avenue for challenging the validity of a regulation, is barred by the provision in section 41 that "no challenge to the validity of a Board order shall be made in any enforcement proceeding . . . as to any issue that could have been raised in a timely petition for review under this Section." The purpose of this is to "eliminate delays in securing compliance with valid Board orders." "It makes good sense as applied to enforcement orders directed at named parties, who can hardly be unaware of the necessity for a prompt appeal; otherwise direct appellate review of those orders could be circumvented by a less efficient trial-court procedure. The requirement of an immediate appeal has been extended to regulations under the federal pollution statutes in order to expedite final judicial determination of their validity and thus their enforcement, ${ }^{82}$ and the constitutionality of such an arrangement was upheld by the United States Supreme Court in the context of wartime price control on the ground that the opportunity for pre-enforcement review was adequate. ${ }^{83}$ Yet in the context of regulations, to require challenges to be made before enforcement "is a harsh measure that may trip the unwary litigant who did not suspect the regulation meant him," 84 and I do not think such a result should be lightly inferred. I at least had no thought that regulations were included in drafting this provision; and excluding regulations from the "orders" for which immediate review is the sole avenue can be reconciled with the fact that regulations are clearly subject to review under section 41 , because that section explicitly makes reviewable not only "orders" but also "determinations" of the Board. ${ }^{85}$

${ }^{81} \mathrm{R}$. OGILvie, supra note 32 , at 5.

8233 U.S.C. § 1369(b) (Supp. II 1972) (water pollution); 42 U.S.C. \& 1857h-5 (1970) (air pollution).

83 Yakus v. United States, 321 U.S. 414 (1944).

si See Currie \& Goodman, supra note 58, at 53.

\&s However, the Administrative Review Act clearly requires a petition for direct appellate review to be filed within thirty-five days after entry of the decision to be reviewed. IL.. REv. STAT. ch. $110, \S 267$ (1973). As applied to regulations, this rule is unfortunate and ought to be changed, for it either deprives the unwary litigant of pre-enforcement review or forces him to seek such review in the circuit court under general injunctive or declaratory provisions. The former alternative seems less in conflict with statutory policy, since the passage of time has no logical bearing on whether trial or appellate court is the appropriate forum; but neither is palatable. 
Finally, although the statute is silent as to the standard for judicial review of regulations, it implicitly dictates that regulations should be set aside if they exceed the statutory authority conferred upon the Board or offend the state or federal constitution. Invoking familiar principles of judicial review of administrative action, the state supreme court has held that a Board regulation "will not be set aside unless it has been clearly arbitrary, unreasonable or capricious." legislative nature "a regulation need not be supported by substantial evidence; rather it will be deemed valid unless shown to be arbitrary, capricious, unreasonable, or otherwise not in accordance with the law." 87 These narrow formulations of the scope of review are fully in accord with the statutory purpose of delegating the authority to resolve difficult questions of technical judgment to the experienced Board.

Thus the provisions for judicial review regulations have so far worked well in practice despite very inept drafting. If and when the statute comes in for amendment, clarification will be in order.

\section{Devising Regulations}

Inheriting an incomplete set of regulations from its predecessors, and observing that "full-fledged enforcement cannot be undertaken until there are adequate rules to enforce," the Board "set as its first priority the complete updating and strengthening of the regulations." 88 After adopting procedural rules ${ }^{89}$ and "a series of relatively narrow and specific new standards to deal with immediate problem situations," such as "accelerating the date for secondary sewage treatment on the Mississippi River . . . ; requiring removal of phosphates from wastes discharged to Lake Michigan . . . ; revising the rules for control of air-pollution episodes . . . ; and providing for strict control of mercury discharged to the water," "90 $_{0}$ the Board in early 1972 completed a comprehensive reexamination of the regulations governing the central fields of air and water pollu-

sz Illinois Coal Operators Ass'n v. PCB, 59 Ill. 2d 305, 319 N.E.2d 782, 785 (1974).

${ }_{87}$ Commonwealth Edison Co. v. PCB, 25 Ill. App. 3d 271, 282, 323 N.E.2d 84, $90-91$ (1st Dist. 1974). See also Armstrong Chemcon, Inc. v. PCB, 18 Ill. App. 3d 753, 310 N.E.2d 648 (1st Dist. 1974) ("manifest weight of the evidence").

D. Currie, The Pollution Control Board: A First Report 1 (Jan. 6, 1971).

so In re Procedural Rules, 1 P.C.B. 43 (1970).

" 1972 PCB AnNual RePoRT 1-2; see In re Mississippi River Treatment Dates, 1 P.C.B. 187 (1971); In re Phosphorus Water Standards, 1 P.C.B. 515 (1971); In re Air Pollution Episode Revisions, 1 P.C.B. 101 (1970); In re Mercury Standards, 1 P.C.B. 411 (1971). 
tion, ${ }^{91}$ and since then has devoted the bulk of its rulemaking attention to "the relatively unexplored fields of noise and solid wastes" and public water supply..$^{93}$ This is not the place for a detailed examination of the particular provisions of the Illinois regulations, which are both of limited applicability and subject to possible revision. But the Board's experience in its first years has cast light on a number of important and recurring problems of general interest.

Pollution control regulations fall into two basic types. On the one hand are air-quality and water-quality standards, which focus upon the receiving medium, the "ambient" air or water into which pollutants are discharged and which itself is breathed or drunk or put to other beneficial uses. On the other are emission or effluent standards, or equipment standards, all of which prescribe maximum acceptable discharges or minimum acceptable control equipment for individual sources of pollution. These two types of regulations serve different purposes, and a balanced body of regulations may well contain both.

\section{A. Air-Quality and Water-Quality Standards}

Because the ultimate goal of any pollution-control program is to protect beneficial uses of the air or water from unnecessary impairment, it makes sense to prescribe contaminant levels in the ambient air and water that may not be exceeded. Not only do such standards provide a partial basis for the design of limitations on particular classes of sources, as will be explored below, but they also serve as independently enforceable measures of the limits of acceptable air and water. They are expressly authorized by sections 10(a) and 13(a) of the Illinois statute.

Almost by definition, standards of air or water quality should bear some relationship to the levels of particular contaminants at which harm is done. Our knowledge on this score is less than complete. In the case of air pollution, the federal government has published a series of documents entitled Air Quality Criteria for half a dozen of the most important contaminants, ${ }^{94}$ summarizing available

"For the most important provisions, see In re Effluent Criteria, 3 P.C.B. $401 \& 755$ (1972) and In re Emission Standards, 4 P.C.B. 298 (1972).

82 PCB, SECOND REPORT 2 (June 28, 1971).

${ }^{93}$ Revised solid waste regulations and new regulations for stationary noise sources were adopted in July 1973, PCB Regs., chs. 7, 8, and revised public water supply rules in November 1973 , id., ch. 6. Proposed regulations on nonreturnable bottles and on transportation noise are pending. See PCB Newsletter \#92, at 2 (1974); \#91, at 2 (1974).

" E.g., U.S. Dep't of Health, Educ. \& Welfare, Air Quality Criteria for Sulfur Oxides (NAPCA PuB. No. AP-50) (1969). 
information as to what concentrations over what period of time will do what kinds of harm to health or public welfare. In the case of water pollution, a single slim volume familiarly known as the Green Book essays to serve the same purpose for the whole range of contaminants. ${ }^{95}$ The result is a bit thin. Illustrative is the following passage, which gives the gist of the Green Book's two-page discussion of the all-important oxygen requirements of fresh-water aquatic life: ${ }^{96}$

Most of the research concerning oxygen requirements for freshwater organisms deals with fish, but since fish depend upon other aquatic species for food and would not remain in an area with an inadequate food supply, it would serve also for the rest of the community . . . . The cold-water fish seem to require higher oxygen concentrations than the warm-water varieties....

It is useless in the present context to know how long an animal can resist death by asphyxiation at low dissolved oxygen concentrations; we must know instead the oxygen concentration that will permit an aquatic population to thrive . . . .

One of the first signs that a fish is being affected by a reduction of dissolved oxygen (DO) concentration is an increase in the rate at which it ventilates its gills . . . . The half dozen or so species (chiefly warm-water game and pan fish) that have been reported so far show a significant increase in frequency as the DO concentration is reduced from 6 to $5 \mathrm{mg} / 1$ (at about $72^{\circ}$ F) and a greater increase from 5 to $4 \mathrm{mg} / \mathrm{l}$. . . . Several field studies have shown, however, that good and diversified fish populations can occur in waters in which the dissolved oxygen concentration is between 6 and $5 \mathrm{mg} / \mathrm{l}$ in the summer, suggesting that a minimum of $6 \mathrm{mg} / \mathrm{l}$ is probably more stringent than necessary for warm-water fishes . . . . In some cases, good populations of warm-water fish, including game and pan fishes, occur in waters in which the dissolved oxygen may be as low as $4 \mathrm{mg} / \mathrm{l}$ for short periods. Three $\mathrm{mg} / \mathrm{l}$ is much too low, however, if normal growth and activity are to be maintained. It has been reported that the growth of young fish is

${ }^{9}$ National Technical Advisory Committee, Report on Water Quality Criteria (1968). See also Cal. State Water Quality Control Bd., Water Quality Criteria (2d ed. J. McKee $\& \mathrm{H}$. Wolf 1963), a more detailed publication on which the Illinois Board placed considerable reliance. For drinking water standards the Board relied heavily on the explanations contained in U.S. Public Health Service, Drinking Water Standards (1962).

9 Report on Water Quality Criteria, supra note 95, at 43-44. 
slowed markedly if the oxygen concentration falls to $3 \mathrm{mg} / \mathrm{l}$ for part of the day, even if it rises as high as $18 \mathrm{mg} / \mathrm{l}$ at other times

An oxygen concentration that can be tolerated by an adult animal, with fully developed respiratory apparatus, less intense metabolic requirements, and the ability to move away from adverse conditions, could easily be too low for eggs and larval stages.

On the basis of this summary, the Green Book recommended that "daily DO concentration should be above $5 \mathrm{mg} / \mathrm{l}$ " and that "under extreme conditions" DO may "range between $5 \mathrm{mg} / \mathrm{l}$ and 4 $\mathrm{mg} / \mathrm{l}$ for short periods," with both daily and short-term standards higher by $1 \mathrm{mg} / \mathrm{l}$ for cold-water fish such as trout and salmon and still higher values in cold-water spawning grounds. This in turn led the Illinois Board to require $6 \mathrm{mg} / \mathrm{l}$ for 16 hours of any day and a minimum of $5 \mathrm{mg} / \mathrm{l}$ : "The present standard (5.0 and 4.0) is not optimum according to the Green Book . . . ."97

The summary nature of the Green Book makes it difficult to assess the validity of the recommendations it contains. Ideally one would like to know whether the experiments relied on were conducted under proper conditions, whether the data base was sufficiently large and sufficiently representative to allow generalization, whether the observations recorded were statistically significant, and whether the results have been accurately summarized. But the Board had inherited a set of standards governing a large variety of contaminants; the desirability of maintaining the breadth of the existing coverage made such detailed investigation impracticable. Since the alternative was simply to repeal the existing standards until a more complete record could be compiled, the Board accepted the Green Book and left it to those affected by the proposed regulations to demonstrate any respects in which it was inaccurate. $\mathrm{Ab}$ sent rebuttal, I think the Green Book is an adequate yardstick of harmful concentrations; but recognition of the uncertain basis of the standards should make the Board sympathetic to arguments for further revisions when better information comes along.

Identification of harmful concentrations is indispensable to the setting of standards of air- or water-quality, but it cannot be the whole story. To begin with, one would scarcely choose to set the standard at a level that has been found to cause harm; some safety margin is necessary simply to avoid known adverse effects. More-

${ }^{97}$ In re Effluent Criteria, 3 P.C.B. 755, 759 (1972). 
over, knowledge is inevitably incomplete: "The exposure levels which have thus far been associated with identifiable [adverse effects . . . are not necessarily the lowest levels of exposure that will produce such effects . . . . Accumulating evidence has almost invariably shown that adverse effects can and do occur at exposure levels that at one time were considered 'safe.' "98 It therefore seems desirable, if other relevant factors permit, to leave a safety margin sufficient not only to avoid known damage but also to give reasonable assurance against unforeseen harm.

These considerations tell us why a safety margin is a good idea but give us very little guidance as to how wide it should be. The Illinois water regulations, which largely followed recommendations from the Green Book and equivalent compilations, reflect no consistent principle in this regard. For example, the silver standard left no margin at all: it was set at a level reported to constitute a "lethal dos[e] to some fish." The copper level was set at $0.02 \mathrm{mg} / \mathrm{l}$ because 0.025 "has been found to kill most fish in 8 hours in the presence of $1.0 \mathrm{mg} / 1$ of zinc"; the cyanide standard was set at half the level that "has killed fish in a short time." the fact that the adverse effect reported, in the case of fish, was generally death; as the above quotation from the Green Book emphasizes, other serious adverse effects may occur at considerably lower levels. The Green Book had attempted to derive safety margins by extrapolation from limited information that compared short-term fatal levels with those that "[did] not adversely affect .. . productivity . . . on continuous exposure." Unfortunately no single conversion factor emerged: for varying pollutants or species "the . . . factor necessary to reduce the concentration low enough to permit spawning ranged from $1 / 7$ to $1 / 500$." ${ }^{100}$ Nevertheless, crude generalizations were drawn to give some semblance of guidance to beleaguered administrators, and the result was standard provisions such as the following: "Any substance toxic to aquatic life shall not exceed one-tenth of the 48-hour median tolerance limit . . . for native fish or essential food organisms." 101

* U.S. Dep't of Health, Educ. \& Welfare, Guidelines for the Development of AIr Quality Standards and Implementation Plans (1969).

" In re Effluent Criteria, 3 P.C.B. 755, 760-61 (1972).

104 Report on Water Quality Criteria, supra note 95, at 56-59.

101 Ill. PCB Regs., ch. 3, Rule 203(h). A final oversimplification in this particular regulation is the unfortunate failure to specify the period of time to which the standard applies; it is easier to meet the same numerical standard on a yearly average than in every grab sample, and the harmful effect of a given concentration generally increases with longer exposure. The absence of any express averaging period and a comparison with the Green Book recommendation from which the regulation was derived ("nonpersistent" pollutants "should not exceed 
Ascertaining the "safe" level of any contaminant is thus a slippery business that is certain to proceed on the basis of incomplete information. Moreover, the Board must not simply require that all air and water be brought to the safe level without regard to cost, for section 27 sensibly requires it in adopting regulations to take into account such matters as "the technical feasibility and economic reasonableness of . . . reducing the particular type of pollution." One cannot, therefore, intelligently set a firm standard of air- or water-quality without some consideration of what it will cost to achieve. One can, however, rationally take "safe" levels as prima facie desirable goals, as the Pollution Control Board did. One can then undertake to ascertain what it will cost to achieve those levels and then make an informed though subjective determination of whether they are worth achieving. This is essentially what was done in the case of air pollution: the federal air-quality standards were taken as the goal; a set of emission-control regulations was devised to meet those standards; the cost was determined to be reasonable; and only thereafter were the air-quality standards incorporated into state law. ${ }^{102}$ The approach taken in the case of water pollution was clearly a poor second best: lacking detailed Institute input relating effluent to ambient quality, the Board presumed that the safe level was the desirable one, in the absence of evidence that it could not be achieved at reasonable cost, making the stricter standards inapplicable to streams that the evidence showed could not reasonably meet them. ${ }^{103}$ Even the first approach falls far short of a full analysis of the marginal costs and benefits of each level of contamination; but it may be about the best we can expect, given the difficulty of quantifying benefits and the practical limitations on administrative access to information. ${ }^{104}$

$1 / 10$ of the 96 -hour TLm value at any time" or $1 / 20$ on a 24 -hour average) suggest that a grab sample is intended.

${ }_{102}$ In re Air Quality Standards, No. R72-2 (May 3, 1973); In re Emission Standards, 4 P.C.B. 298 (1972).

${ }^{103}$ In re Effluent Standards, 3 P.C.B. 755 (1972). In the case of water, it is possible to set "safe" levels for various uses and then to take cost into account in designating the uses for which each body of water is to be protected. This approach has the advantage of stating a clear goal. It is more difficult in the case of air, which must be breathable everywhere. Further consideration of cost is assured by the statutory provision that unreasonable cost is a defense to a charge of violating the regulations ( $\$ 31(\mathrm{c})$ ); and cost is also the basis for the mixing-zone limitations on water-quality standards discussed in text and notes at notes 115 22 infra.

104 Even the most conscientious efforts to set rational levels of air- or water-quality may fail, as is soberingly demonstrated in Ackerman, Ackerman, \& Henderson, The Uncertain Search for Environmental Policy: The Costs and Benefits of Controlling Pollution Along the Delaware River, 121 U. PA. L. REv. 1225 (1973). 
The Illinois standards are typical in specifying their own inapplicability under limited circumstances: The air-quality standards are not to be exceeded more than one day a year, and the water standards are lifted "when flows are less than the average minimum seven day low flow which occurs once in ten years." 105 Such provisions reflect the fact that air- and water-quality standards serve as bases for designing control equipment. It would seem, however, that a program is deficient if it permits all the fish to be wiped out-or, in the case of air pollution, all the people-even once every ten years. One could avoid this problem and yet provide a basis for efficient design by making the ambient standards applicable at all times, basing normal treatment requirements on a reasonable worst-conditions assumption, and requiring emergency measures to meet the standard at other times. Yet absolute compliance with the standards may come at a high price; the exceptions suggest that we do not know the costs and benefits of maintaining a firm standard in extreme conditions. In any event, protection under such circumstances is given by the statutory provisions forbidding air or water pollution under all circumstances and making the cost of control relevant to the determination of each case. ${ }^{108}$ Additional assurance is given by regulations requiring curtailment of production when specified danger levels of air contamination are reached, pursuant to detailed advance plans, ${ }^{107}$ and the Board has indicated that it may adopt comparable provisions for water pollution. ${ }^{108}$

\section{B. Implementation of Air- and Water-Quality Standards}

Standards of air- or water-quality, the Illinois Board has said, "tell us the limits of tolerable air, but they do not tell us how we are to avoid worse. We cannot punish the air if the standard is exceeded . . . ."109 Illinois regulations do expressly prohibit emissions that "prevent the attainment or maintenance of any applicable ambient air quality standard," 110 and the comparable water provision $^{111}$ goes on to say that the Agency shall use its permit or complaint powers "to require the [offending] discharge to meet what-

105 PCB Regs., ch. 2, Part III; ch. 3, Rule 202.

$100 \$ \S 9(\mathrm{a}), 12(\mathrm{a}), 33(\mathrm{c})$.

${ }^{107}$ PCB Regs., ch. 2, Part IV.

19x In re Effluent Standards, 3 P.C.B. 755, 758 (1972). Sections 34(b) and 43 of the statute allow injunctions and summary executive action in emergency situations, but only when the threat is to "health," or, under a recent amendment, to "livelihood."

100 In re Emission Standards, 4 P.C.B. 298, 308 (1972).

110 PCB Regs., ch. 2, Rule 102.

III Id, ch. 3, Rule 402. 
ever effluent limits are necessary to ensure compliance with the water quality standards." But these provisions require a cumbersome case-by-case determination of the relation between discharge and ambient conditions. Moreover, when, as often occurs, an excessive ambient level is the result of discharges from more than one source, the determination of who is to do what about it may become exceedingly complex. Although the Illinois water regulation provides for joinder of several polluters in a single proceeding and for necessary effluent reductions to be "determined on the basis of technical feasibility, economic reasonableness, and fairness to all dischargers," the fact remains that an enforcement proceeding against multiple parties is scarcely the most appropriate vehicle for constructing a program to bring a major city's air or a major river into compliance with the quality standards. ${ }^{12}$

The implementation plan is a means for ameliorating the difficulties of direct enforcement of standards of air- or water-quality. Pursuant to federal statutory provisions for state enforcement of federal air-quality standards, ${ }^{113}$ an air implementation plan must give assurance of adequate authority and resources for information and enforcement. The real teeth are found in the requirement of "emission limitations, schedules, and timetables for compliance .... , and such other measures as may be necessary to insure attainment and maintenance of such [air quality] ... standard." 114 As the Illinois Board has put it, "[ $t]$ he heart of any control program, and thus the working part of an implementation plan, is a set of regulations . . . directly limiting emissions from individual and area sources." 115 The problem then becomes how to devise emission or effluent standards tight enough to ensure that air or water quality standards will not be exceeded.

One way to make sure that the ambient air or water meets the standard is to require that everything discharged into it meet the standard. Indeed, this is the only way in which the standard can be met everywhere; whenever a discharge standard is more lenient than the ambient standard there will be a "mixing zone" in which the latter is exceeded.

Sometimes, when standard technology at acceptable cost (obviously not a self-defining criterion) is capable of making an effluent itself meet the stream standard, use of that technology has indeed

112 See In re Emission Standards, 4 P.C.B. 298, 308 (1972).

11 Clean Air Act \& 110, 42 U.S.C. \& 1857c-5 (1970).

i' Id. $\S 110(\mathrm{a})(2)(\mathrm{B}), 42$ U.S.C. $\S 1857 \mathrm{c}-5(\mathrm{a})(2)(\mathrm{B})(1970)$.

115 In re Emission Standards, 4 P.C.B. 298, 308 (1972). 
been required. The Board found, for example, the Illinois effluent and stream standards for lead $(0.1 \mathrm{mg} / 1)$ could be achieved by lime precipitation for costs equivalent to conventional secondary sewage treatment. ${ }^{116}$ It is not always so easy, however, to make what comes out of the smokestack or sewer clean enough to breathe or to drink directly. For example, the Illinois Board set an ambient phosphorus standard of $0.007 \mathrm{mg} / 1$ as indispensable to protect Lake Michigan from overfertilization such as had overtaken Lake Erie; yet in the same order the Board set an effluent standard for phosphorus at 1.0 $\mathrm{mg} / \mathrm{l}$, "representing the application of the maximum feasible technology for phosphorus removal" from municipal sewage (ninety percent, by chemical precipitation) short of enormously expensive techniques such as ion exchange or electrodialysis costing five or more times as much as precipitation. ${ }^{117}$ Similarly, although the ambient-air standard for carbon monoxide is 9 p.p.m., ${ }^{118}$ the Illinois Board found that at best foundry emissions could be reduced by means of a ninety-percent-plus efficient afterburner to 200 p.p.m. ${ }^{119}$ To make every discharge standard as stringent as the ambient standard, the Board concluded, "would impose an unreasonable cost burden" even if the technology was available. ${ }^{120}$

Consequently, air emission standards generally require no more than what can be achieved by a given level of control technology, and stacks are relied upon to disperse the remaining pollutants. ${ }^{121}$ It is implicit that air-quality measurements will not be taken at the top of the stack; it is anticipated that nobody will be there to be hurt. In water pollution control a portion of the stream is explicitly sacrificed for economic or technological reasons. The Illinois provision is typical: "Whenever a water quality standard is more restrictive than its corresponding effluent standard then an opportunity shall be allowed for the mixture of an effluent with its receiving waters." 122

118 PCB Regs., ch. 3, Rules 203(f), 408; In re Effluent Standards, 3 P.C.B. 755, 761-62 (1972); 3 P.C.B. 401, 416-20 (1972). Even in such a case one must ask whether it is worth the cost to require such treatment if in-stream dilution will dissipate the excessive contaminant within a short distance.

${ }_{117}$ In re Phosphorous Water Standards, 1 P.C.B. 515, 521-22 (1971).

11s PCB Regs., ch. 2, Rule 310.

is See In re Emission Standards, 4 P.C.B. 298, 341 (1972).

${ }^{120}$ In re Effluent Standards, 3 P.C.B. 755, 757 (1972).

121 See, e.g., Ill. PCB Regs., ch. 2, Rule 110, requiring "stacks or vents" to prevent violation of any air-quality standard.

${ }_{122}$ PCB Regs., ch. 3, Rule 201(a). An alternative considered by the Board but not discussed in its opinions was to require reasonable treatment followed by dilution before discharge, so that no part of the stream would violate the water-quality standard. The idea was 
Once it is found unreasonable to require all discharges to be as clean as the ambient air- or water-quality standard would dictate, one must select a tentative emission control strategy on the basis of factors such as feasibility, cost, and fairness and then predict whether or not it will achieve compliance with the ambient standard. In the absence of better information, the Board employed a simplified "dilution ratio" test in setting certain of its effluent standards: if a given stream will dilute the wastewater with an equal volume of clean water, discharges at twice the level prescribed by the water-quality standard will permit the stream to comply after complete mixing. ${ }^{123}$ Similar in degree of sophistication is the "proportional" or "rollback" formula approved by the federal air regulations: making allowance for background levels, if the ambient standard is now exceeded by a factor of two, emissions must be halved

abandoned after informal investigation suggested that it would impose significant energy costs for pumping and cause damage to organisms drawn through the plant in the dilution water.

On the other hand, a state could carry the mixing zone concept to extremes by allowing any discharge that would meet the ambient standard after full mixing had taken place. But this approach might result in noncompliance with the standard in a substantial portion of the stream. The Illinois standard expresses this concern while remaining vague as to what to do about it: "The governing principle is that the proportion of any body of water or segment thereof within mixing zones must be quite small if the water quality standards are to have any meaning. This principle shall be applied on a case-by-case basis [initially through the permit process] to ensure that neither any individual source nor the aggregate of sources shall cause excessive zones to exceed the standards. The water quality standards must be met in the bulk of the body of water . . . ." Id. Certain factors are prescribed for consideration: the "character" [?] of the body of water, its present and anticipated uses and water quality, the effect of the discharge, the dilution ratio, and the nature of the contaminant. Oddly, the cost of reducing the size of the zone is not expressly mentioned. An outer limit is prescribed, taken from pre-existing guidelines without explanation: "No single mixing zone shall exceed the area of a circle with a radius of 600 feet." Moreover, in water designated for aquatic life, mixing zones must assure a reasonable zone of passage for aquatic life in which the water quality standards are met, and the mixing zone must not adversely affect "the maintenance of aquatic life in the body of water as a whole"-such as by destroying important spawning grounds.

${ }_{123}$ See, e.g., id. Rule 404, setting effluent standards for plants treating domestic sewage. The basic standards, subject to complications not here relevant, are expressed in the following table:

$\begin{array}{cc}\frac{\text { Dilution Ratio }}{<1: 1} & \text { BOD }_{5} \frac{(\mathrm{mg} / 1)}{4} \\ \text { between } 1: 1 \text { and } 5: 1 & 10 \\ >5: 1 & 20\end{array}$

Compliance with this table will produce disuniform stream levels of biochemical oxygen demand (BOD) because sewage treatment is largely a stepwise process; often, to reduce effluent levels a little requires construction of an additional stage that will reduce them a lot. The levels in the table represent standard secondary treatment and two degrees of more advanced (tertiary) control. 
to achieve compliance. ${ }^{124}$ Such approaches are obviously quite crude. The rollback model "does not account for topography, spatial distribution of emissions, or stack height,"125 while the dilution ratio without more ignores pollutants that are already in the stream. ${ }^{128}$ Consequently, more complex mathematical "models" have been widely used in determining the adequacy of proposed control strategies under the federal air statute, in Illinois and elsewhere. ${ }^{127}$

Mathematical models, within the limits of their accuracy, help in evaluating whether a proposed emission control strategy is strict enough to achieve compliance with standards of air or water quality; but they cannot eliminate the necessity for basic policy choices. A requirement that each discharger reduce his contribution by the same proportion would be unfair to those who had already installed better than average controls. An equal allotment in dischargeable pounds per day to each polluter would discriminate against those with larger and more productive plants. A universal pounds-perunit-of-production standard could ruin industries with special difficulties of control. To require emission reductions from those who could make them most cheaply ${ }^{128}$ would minimize the cost to society, but would raise issues of equity. An economist might suggest that emission rights be distributed to all property owners on a peracre basis and made transferable on the free market. ${ }^{28}$ Apart from the problem that an emission from one place and at one altitude

121 See 40 C.F.R. $\$ 51.13(\mathrm{e})(2)(\mathrm{ii})(1974)$.

125 Id.

120 Moreover, BOD is not the parameter that is of ultimate concern. It is a measure of the oxygen-consuming capacity of the effluent and is important because a high BOD level will depress dissolved oxygen to the detriment of aquatic life such as fish. And the relation between BOD and dissolved oxygen levels is not constant, as the Illinois Board found in declining to adopt a stream standard for BOD: "The evidence is that the effect of a given level of BOD on a stream is too dependent upon reaeration rates to make any prescribed standard meaningful." In re Effluent Standards, 3 P.C.B. 755, 759 (1972). Consequently an exception from the strict $4 \mathrm{mg} / 1 \mathrm{BOD}$ s standard was provided for most individual sources upon proof that an effluent of $10 \mathrm{mg} / 1$ would enable them to meet all applicable water-quality standards, considering the quantity and quality of available dilution water, the reaeration rate, and any other relevant factors. PCB Regs., ch. 3, Rule 404(f)(2). See In re Effluent Standards, supra, at 768-71 (1972) (estimating that this exception would reduce tertiary treatment costs at three medium-sized municipal plants from $\$ 11,000,000$ to $\$ 3,000,000$, making funds more readily available for such critical additional needs as ammonia nitrification and control of stormwater overflows).

${ }^{127}$ E.g., 1 Illinois EPA, State of Illinois Air Pollution Implementation Plan, 4-2-1, 42-2 (1972). For a sobering view of the dangers of inaccuracy in devising a comparably sophisticated water pollution model, see Ackerman, Ackerman \& Sawyer, The Uncertain Search for Enviranmental Policy: Scientific Factfinding and Rational Decisionmaking Along the Delaware River, 120 U. PA. L. Rev. 419, 479-80 (1972).

${ }_{128}$ See Kohn, Achieving Air Quality Goals at Minimum Cost, 1968 Wash. U.L.Q. 325.

12 Cf., e.g., J. Dales, Pollution, Property \& Prices 93-97 (1968). 
may have different effects than an equivalent emission elsewhere, the costs of transacting might pose significant obstacles to the operation of the market. ${ }^{130}$ Still, the idea bears further consideration.

In designing to meet the particulate standard, the Illinois agencies essentially started by determining what air quality would result if the most significant large sources employed a high level of control technology deemed to be available without prohibitive cost. When that proved insufficient for Chicago, the conversion of small coalburning sources to gas was considered and was found both sufficient and achievable at a cost that was reasonable in light of the need..$^{131}$

Fortunately the Board did not have to reach the intimidating problem of what to do if the best available technology is insufficient to maintain satisfactory air-quality. If the problem is only new sources, they can be sent elsewhere at the expense of growth. This is draconian enough and may counsel reexamination of whether enforcement of the ambient standard is really worth the cost. The question becomes still more acute if existing sources cannot be made

${ }^{130}$ Cf. Coase, The Problem of Social Cost, 3 J. Law \& Econ. 1 (1960).

131 In re Emission Standards, 4 P.C.B. 298, 324-28 (1972).

In older cities such as Chicago and East St. Louis there remain a considerable number of small sources burning coal for heating purposes, especially in small apartment buildings. The Agency tells us that particulate emissions from such sources, which are commonly uncontrolled, are as high as $1.0 \mathrm{lb} / \mathrm{MBtu}$. . . . Not only do these emissions grossly exceed what is allowed from other sources, but . . . diffusion studies show that because small domestic and commercial sources emit generally at low altitudes from poorly designed stacks or vents, their effect on air quality is disproportionally large in respect to absolute quantities of emissions. . . . In the Chicago area the evidence is absolutely indisputable that control of small coal-burning sources is essential. Regardless of what other feasible controls are imposed, not even the primary federal standard of $75 \mu \mathrm{g} / \mathrm{m}$, much less the secondary standard of 60 , can be met in most of the City without control of domestic and commercial coal burning . . . .

The practicability of eliminating these principal sources of Chicago's remaining pollution problem is amply sustained by the record . . . .

The cost of conversion, while it may be recoverable in lower fuel costs, is nevertheless a significant one ( $\$ 300-\$ 700$ per dwelling unit according to Argonne . . .) for individuals of modest means, many of whom will be affected by the conversion requirement. We think in the Chicago area these costs simply must be borne if we are to have clean air. The federal criteria showing the adverse effects of high particulate concentrations such as would continue to be experienced without such a requirement suggest that the cost would be easily made up for in savings to the entire community from reduced pollution . . . . We are quite aware that the limitation will have adverse effects on those who now supply coal to the dwindling retail market. But to refuse to adopt needed control measures for the sake of the coal merchants would be akin to fighting a war to keep the soldiers employed. We cannot preserve retail coal sellers at the expense of the public health. As urged by citizen witnesses testifying in favor of a limitation on domestic and commercial coal-burning . . . , we think local and state lawmakers should give serious consideration to some form of government assistance for all those adversely affected. 
to yield compliance with the ambient standards. No tools come readily to mind for determining which shall be shut down, if even in those circumstances one concludes that the ambient standard must be met.

The Illinois air regulations, because of the sophisticated modeling conducted by the Institute through its contractor, Argonne $\mathrm{Na}$ tional Laboratory, have been tailored closely to need and pre-tested to determine their adequacy. The water regulations, however, are in much less satisfactory shape. We have both effluent and water quality standards governing a broad range of contaminants, but we have no assurance in most cases that compliance with the effluent standards will achieve the prescribed water quality. In this instance the separation of Institute research capability from Board control has proved frustrating, for the Board's request that the Institute propose an implementation plan for water as it did for air has so far fallen on deaf ears.

\section{Beyond Standards of Air- and Water-Quality}

Not all Illinois effluent and emission standards are carefully tailored to assuring present compliance with air- or water-quality standards. "We have in a number of cases," said the Board, "imposed state-wide emission standards that must be met everywhere as a modicum of good practice." ${ }^{132}$ Such uniform discharge standards have precedents in the actions of predecessor agencies requiring particulate control and secondary treatment throughout the state $^{133}$ and analogues in federal requirements of the best practicable or best available treatment for certain air or water pollution sources. ${ }^{134}$ The new Board, similarly, adopted for example uniform state-wide emission standards for carbon monoxide; ${ }^{135}$ and most of its effluent standards for water pollutanis, in the absence of adequate information relating effluents to water quality, are of this type. ${ }^{136}$

There is no doubt that to require the same level of control everywhere is a crude method of achieving the ultimate goal of preventing excessive harm from pollution. In some places there may be so much clean air or water to dilute the discharge that the am-

132 Id. at 309.

13s See Id.

134 Federal Water Pollution Control Act $\S \S 301,306,33$ U.S.C. $\$ \S 1311,1316$ (1970);

Clean Air Act § 111, 42 U.S.C. § 1857c-6 (1970).

135 PCB Regs., ch. 2, Rule 206.

136 See Id, ch. 3, Rule 408. 
bient standard could be met without treatment; in others there may be so little clean air or water left that compliance with the discharge standard will not prevent an ambient violation. The Board attacked the latter half of this problem by adopting separate provisions making it unlawful, despite compliance with numerical discharge standards, to cause a violation of an air- or water-quality standard. ${ }^{137}$ The more serious objection is that state-wide standards may be tighter than necessary, and that they represent a policy of cleanliness for its own sake in disregard of both good sense and the statutory requirement that the cost of compliance be weighed against the benefits.

The Board gave several responses to this argument. The first recognized the practical difficulties of gathering the information required to make a precise assessment of costs and benefits: seeking to tailor the effluent standard for each source to bare compliance with the water-quality standard "would be an overwhelming administrative task." 138 The alternative to effluent standards based upon reasonable treatment requirements was no effluent standards at all beyond the general injunction not to cause violations of waterquality standards-a rule too vague to promote much voluntary compliance. If and when stream-by-stream information became available, the standards might be improved upon, but in the meantime something had to be done, and the discharger who could show the required control to be an unreasonable waste of money could get a variance.

But the Board also gave affirmative reasons for deeming it desirable in some cases to require treatment beyond that required to achieve immediate minimum compliance with ambient standards. The first derived from the fact that the ambient standards must be met in the future as well as today: uniform standards "make allowance for anticipated growth and development .... We cannot allow present emission sources to use up the entire assimilative capacity of the air without robbing the future of the opportunity for growth." ${ }^{39}$ The final argument was more sweeping, asserting that there were some significant benefits in keeping the air or water considerably cleaner than the ambient standards: "[a]ir quality standards are set not at the optimum level of air quality, but at the worst level we are prepared to tolerate if we must." 140

137 Id, ch. 2, Rule 102; Id. ch. 3, Rule 402.

${ }_{138}$ In re Effluent Criteria, 3 P.C.B. 401,410 (1972).

${ }^{130}$ In re Emission Standards, 4 P.C.B. 298, 309 (1972).

${ }^{140}$ Id. A variant of this last argument is that uniform discharge standards help to discour- 
Nevertheless the Board refused to take a dogmatic position on the underlying philosophical controversy of best treatment versus assimilative capacity. For example, it required cooling towers only for future hot-water dischargers to Lake Michigan, concluding after extensive hearings that to install them on existing sources would be a waste of money; ${ }^{141}$ and it limited its strict sulfur-dioxide emission standards to three problem geographical areas because of the novelty of the control technology and the desire not to divert scarce clean fuels from areas where they were most needed..$^{142}$ In determining whether to set uniform discharge standards, as in setting any other discharge standards, the Board attempted to make some comparison of benefits and costs. On the cost side the Board often had reasonably useful information. For example, the Institute had compiled an impressive literature survey reporting the effluent levels of a variety of contaminants achievable at what cost by varying treatment methods. ${ }^{143}$ But to find that something can be done at less than prohibitive cost does not prove it is worth doing, and as usual the benefits of achieving various effluent levels largely defied quantification.

One solution the Board found was to use ambient standards as a rough index of the benefits of strict discharge limits. With respect to a number of metallic water contaminants, for example, the record left the Board with essentially three alternatives: no treatment; precipitation with lime, to remove ninety percent or so of the contaminants at a cost said to be roughly equivalent to that of secondary sewage treatment, which had been required state-wide for some years; or such techniques as ion exchange, often at costs five to ten times those of precipitation, to remove virtually everything. ${ }^{14}$ The Board opted for the intermediate requirement with great consistency. In some cases precipitation would achieve an effluent clean enough itself to satisfy the water quality standard, ${ }^{145}$

age "competitive discrepancies that might tend to concentrate sources in areas now clean." Id. The further contention that uniform discharge standards may help prevent "local nuisances," id., is based upon the fact that ambient standards often incorporate mixing zone provisions allowing harmful levels to exist locally. Given adequate information, such nuisances could be reduced, where that is economically reasonable, by reducing the size of the mixing zone.

11 In re Lake Michigan Thermal Standards, 1 P.C.B. 697 (1971).

112 In re Emission Standards, 4 P.C.B. 298, 334-35 (1972).

14 Wastewater Treatment Technology (IIEQ Doc. No. 71-4) (1971).

14 There was insufficient information as to the costs of complete recycling of treated effluents, which would avoid all discharge beyond the "blowdown" necessary to avoid excessive buildup of salts damaging to industrial processes.

is Lead, nickel, and zinc. In re Effluent Criteria, 3 P.C.B. 401, 416, 417, 420 (1972). 
a beneficial result because it would eliminate mixing zones in which harmful levels would otherwise prevail. In other cases precipitation would significantly reduce the size of the mixing zone because only a modest volume of stream water would be required for dilution to meet the ambient standard. ${ }^{146}$ The urge to eliminate mixing zones altogether by requiring substantially greater expenditures was rejected. ${ }^{147}$ For sulfates and chlorides, which cannot be precipitated with lime, the Board required no treatment at all because of the low toxicity of the contaminants and the high cost of control: chloride and sulfate standards "would impose the highest treatment costs of any here under consideration in order to do the least good."148

All of this was very far from a fully informed comparison of costs and benefits. It may represent about as much as could reasonably have been expected in light of the administrative costs of doing better. But the decisions reached were soberingly subjective, and recognition of this fact should make the Board sympathetic to requests for revision of the standards as better information becomes available.

Arguments very similar to those that determine the desirability of uniform discharge standards underlie the continuing controversy over non-degradation. ${ }^{149} \mathrm{On}$ the one hand it is argued that there is no benefit in forbidding areas now clean to deteriorate to air or water quality standards, since by hypothesis those standards represent levels at which no harm is done. The counterarguments are that assimilative capacity should be rationed to leave room for growth and that the ambient standards may not prevent all harm after all.

A blanket prohibition on all degradation of existing air- or water-quality would outlaw every new source discharging anything and would obviously be unacceptable. The Illinois Board therefore adopted a standard preventing unjustifiable degradation as determined in individual permit or enforcement proceedings ${ }^{150}$-a safe

1 146 E.g., cadmium (effluent standard $0.15 \mathrm{mg} / \mathrm{l}$, ambient standard 0.01 ); fluoride (2.5 and $0.01)$. Id. at 413,415 .

${ }_{17}$ One of the larger mixing zones permitted was for copper (effluent standard $1.0 \mathrm{mg} / \mathrm{l}$, ambient standard 0.02). Id. at 414-15.

14 Id. at 413.

149 See Sierra Club v. Ruckelshaus, 344 F. Supp. 253 (D.D.C. 1972), aff'd mem. Civil No. 1031-72 (D.C. Cir., filed Nov. 1, 1972), aff'd by an equally divided Court, 412 U.S. 541 (1973).

150 Existing ambient air quality which is better than the established ambient air quality standards at the date of their adoption will be maintained in its present high quality. Such ambient air quality shall not be lowered unless and until it is proved to the Agency that such change is justifiable as a result of necessary economic and social development and will not interfere with or become injurious to human health or welfare.

PCB Regs., ch. 2, Rule 303. See also id. ch. 3, Rule 208 (water). These provisions are enforce- 
regulation in that it opts for neither too much nor too little degradation, but one that leaves all new development in considerable uncertainty and should prove costly to enforce. It is probably better than simply allowing all degradation until the ambient standards are reached, but the Board should strive to make it more specific.

To some degree the policy of preventing unnecessary degradation can be served by uniform discharge standards; for example, the federal non-degradation regulation for air requires best practicable control as a first step. ${ }^{151}$ Such standards will help to allocate assimilative capacity fairly between present and future sources, but they cannot permanently keep the air or water from approaching the ambient standard. The question then arises whether there are certain geographical areas which, because of their special esthetic or recreational values, ought to be given further permanent protection. The Illinois Board did just this in the case of Lake Michigan, by setting unusually stringent water-quality standards based essentially upon existing water-quality; ${ }^{152}$ it also proposed to do the same for other bodies of water but postponed the idea because no one produced any evidence to indicate which waters should be included. ${ }^{153}$ Such a zoning approach, which singles out areas in which there is thought to be substantial benefit in preserving pristine as opposed to merely harmless air or water, has much to recommend it, and it is the approach recently adopted by the federal EPA. ${ }^{154}$ Upon delimitation of such areas and adoption of whatever uniform treatment requirements appear reasonable, uncertainty-provoking general provisions against unnecessary or unjustifiable degradation can profitably be repealed.

\section{Some Technical Problems in Drafting Discharge Standards}

The conscientious rulemaker will quickly discover that in setting discharge standards he cannot simply set forth a number and go out to play golf. He must make provisions respecting such irritating details as testing methods, averaging periods, background conditions, upsets, and dilution in lieu of treatment. He must also deal with a variety of methods of expressing a single idea: shall he

able by the Agency in passing on permit applications and by complaints before the Board. Id. ch. 2, Rule 103(a)(5), ch. 3, Rule 921(a); Environmental Protection Act $\S$ 9(a), 12(a), 31.

15140 C.F.R. $\$ 52.21$ (1974).

152 PCB Regs., ch. 3, Rule 206.

15s In re Effluent Criteria, 3 P.C.B. 755, 764-65 (1972).

15140 C.F.R. $\$ 52.21$ (1974), (leaving to the states the designation of areas entitied to preservation of existing air quality). 
prescribe the use of particular control equipment, limit the concentration of the discharge, or limit the weight of contaminants discharged per day or per unit of production?

Many of these questions largely solve themselves if the basis on which the standards are set is kept firmly in mind. The Illinois Board generally has set discharge standards to reflect what can be achieved by available control technology at reasonable cost. It follows that compliance should be tested by the same methods and over the same averaging periods that were used in determining what discharge level could be reasonably achieved. ${ }^{155}$ It follows that whether a standard applies to total iron or only to that which is dissolved depends upon which parameter was measured in the tests on which the regulation is grounded. ${ }^{156}$ It follows that background levels of contaminants in the intake water should be taken into account only to the extent that they impair the ability of the control equipment to achieve the tested level. ${ }^{157}$ It follows that dilution, which is less effective in protecting ambient quality, should not be allowed in lieu of treatment. ${ }^{158}$ And it suggests, in the first instance,

135 Thus there is room for error in PCB Regs., ch. 3, Rule 105, which prescribes those testing methods found in the standard reference work, American Public Health Association, Standard Methods for the Examination of Water \& Waste Water (13th ed. 1971), or "other generally accepted procedures." Still worse was the rejected alternative, which would have allowed the Agency-an interested party-to specify any alternative procedures. In re Effluent Criteria, 3 P.C.B. 401, 403 (1972). Rule 401(c) of the water rules allows averaging because of considerations of achievability, but does not give firm information as to averaging times in the tests on which the standards were based. See id. at 405.

${ }^{156}$ Most Illinois effluent standards apply to total, not merely dissolved, contaminants: "the basic treatment processes contemplated by the proposed standards . . . will readily allow removal of suspended as well as of dissolved contaminants to the levels described." In re Effluent Criteria, 3 P.C.B. 401, 411 (1972).

${ }^{157}$ The Board basically said that no allowance would be made for background levels because "the types of treatment necessary to meet the proposed standards are principally limited by ultimate concentrations and not likely to be seriously affected by relatively low background levels." Id. at 404 . But the Board also suggested that credit might have been denied even if background levels significantly impaired effluent quality: to give credit for background "would permit progressive deterioration of stream quality as one passes downstream." Id. This line of argument rested on a policy judgment not consistent with the ideal of keying effluent standards to practicability; the problem of progressive deterioration, if it had arisen, should have been taken into account after further analysis of the costs and benefits of various treatment alternatives.

Meanwhile, the Board made clear it did not think the benefits justified the costs of cleanup when without background contamination no treatment would be required: "we do not wish to require expensive treatment processes to be installed simply to clean up what has been put into the water by upstream users or to remove traces of materials that it is not worth the cost of removing." Id. at 404 . Because of this complication, the rule states a rather vague principle whose application is left to the Agency on a case-by-case basis, PCB Regs., ch. 3, Rule 401(b).

${ }^{158}$ The Board modified this conclusion slightly in order not to forbid combining two or 
that exceptions ought to be made for times when startup, breakdown, or other abnormal conditions make it impossible for the control equipment to achieve the emission level attainable under ordinary conditions.

It is consistent with the practicability principle to require reasonable maintenance of control equipment, and safeguards such as multiple units or holding tanks to the extent they are costjustified. ${ }^{159}$ But quite a different principle dictated the rule that, "except in special cases, equipment whose [air] pollution controls are out of order should not be operated, just as an automobile should not be operated when its brakes are out of commission." If such a provision is desirable, it is because the benefits of a shutdown exceed the costs; its desirability does not follow from the supposition that it is reasonable to require meeting the emission standards under normal conditions. In fact the Board, recognizing that "it may not be worth blacking out the entire Midwest to prevent emissions from a partly malfunctioning boiler precipitator," gave the Agency authority in issuing permits to allow emissions exceeding the standards during abnormal periods upon proof of special need..$^{160}$

Standards prescribing or proscribing particular classes of equipment, fuels, and so forth, often have the advantage of easy enforcement: it is cheaper to analyze a handful of coal or to determine whether a baghouse is attached than it is to run a complex stack test. Such requirements can also be imposed, and not infrequently are, when there is insufficient information to determine the level of emissions that can be expected from using certain technology. ${ }^{161}$ On the other hand, our real concern is with results, not with how they are attained; in an equipment or fuel standard, if unnecessary costs are not to be imposed, one must include an escape clause allowing alternative means of achieving the equivalent emissions.

more wastewater streams before treatment where to do so would significantly reduce costs. The resulting rule is therefore rather vague. PCB Regs., ch. 3, Rule 401(a); see In re Effluent Criteria, 3 P.C.B. 401, 403-04 (1972).

ist See PCB Regs., ch. 3, Rule 601(a) (requiring wastewater works to be "so constructed and operated as to minimize violations of applicable standards" during abnormal conditions but leaving to individual determination what such measures are "appropriate").

100 PCB Regs., ch. 2, Rule 105; see In re Emission Standards, 4 P.C.B. 298, 305 (1972).

Yet the criteria for operation during breakdowns appear excessively strict: the applicant must show that "continued operation is necessary to prevent injury to persons or severe damage to equipment . . . or to provide essential services; . . . the economic benefit of the owner or operator shall not be a sufficient reason."

161 See, e.g., In re Emission Standards, 4 P.C.B. 298, 320-21 (1972) (control of coke-oven emissions). 
Moreover, installation of excellent control equipment is not enough; some provision must be inserted to assure that it operates effectively, and this necessity pushes toward adoption of numerical standards.

Standards setting maximum contaminant concentrations in such terms as milligrams per liter or grains per cubic meter are common because measurements are often reported on a concentration basis; they can be translated into total pounds per unit of production by the use of information about the total volume of emissions and the quantity of production. Special dilution provisions are unnecessary if a weight standard is used. Background concentrations tend under such standards to be charged against the discharger unless special allowance is made. The choice among ways of expressing standards ought not to obscure the fact that there are significant policy decisions to be made on these issues. Finally, a concentration standard without an escape clause discourages recycling: Although recycling may substantially reduce the total poundage of pollutants discharged, the small volume of effluent that must be drawn off during recycling in order to keep dissolved solids from building up to levels harmful to plant equipment may not be discharged because its concentration exceeds the standard. There is another side to this coin, as usual: the discharge of even a small volume of highly concentrated pollutant may create a "hot spot" in which serious damage is done to the stream.

\section{Judicial RESPONSE}

It is too early to detect any consistent patterns in judicial review of Pollution Control Board regulations, as only a few have so far been passed upon. The decisions so far can best be described as looking in various directions.

Several of the decisions have resolved broad straightforward questions of statutory or constitutional authority. I have already discussed cases upholding the delegations of quasi-legislative power ${ }^{162}$ and the trial-court decision in Gromer Supermarket, Inc. $v$. $P C B,{ }^{163}$ holding the Board without power to require deposits on beverage containers; the specific question in Gromer remains open because the decision was set aside as premature. ${ }^{164}$ Illinois Coal Operators Association v. $P C B,{ }^{165}$ also discussed earlier, held that the

\footnotetext{
${ }^{162}$ See text and notes at notes 9-15 supra.

${ }^{163} 6$ III. App. 3d 1036, 287 N.E.2d 1 (1st Dist. 1972).

Ist See text and notes at notes $32-43$ supra.

16559 Ill.2d 305, 319 N.E.2d 782 (1964).
} 
noise-nuisance regulation did not exceed the statutory power to prevent unreasonable noise. ${ }^{168}$ And $W . F$. Hall Printing Co. v. EPA ${ }^{167}$ established a principle essential to any rulemaking program. A printing company charged with emitting odors violating the statutory nuisance provision argued that it had been denied equal protection because the Board had adopted specific regulations governing odors from another industry. The court responded:

The Board is presumed to have the expertise to determine which aspects of the pollution problem are most susceptible to fixed regulations and most worthy of the expenditure of time and money necessitated by the procedure for promulgation of substantive regulations . . . As the legislature's delegate, the Board may, like the legislature, "take one step at a time, addressing itself to the phase of the problem which seems most acute ...". . To require the Board to adopt regulations for all types of pollution, or even for all sources of odors, would ... discourage the Board from adopting any regulations at all unless the entire field of pollution could be regulated at the same moment, a colossal and time-consuming undertaking .... ${ }^{168}$

In Hall, the plaintiff's argument was that those subject to a specific regulation had the benefit of greater certainty as to what the law required. The policies the court relied on would seem equally applicable if the reverse contention were made-if those subject to a regulation were to argue that it was unconstitutional for the Board to fail to pass regulations governing other industries. This line of argument would be especially weak since all must comply with the nuisance provisions in the statute or in the regulations. On the other hand, if both industries were subject to specific regulations, presumably there would have to be some justification for treating one more harshly than another. ${ }^{169}$

Of considerable significance for the control program is the decision in A. E. Staley Manufacturing Co. v. EPA, ${ }^{170}$ upholding regulations limiting discharges to sewers despite the absence of explicit statutory language conferring such authority. It was enough, said the court, that "there is a realistic and practical nexus between

166 See text and notes at note 21 supra.

16716 Ill. App. 3d 864, 306 N.E.2d 595 (1st Dist. 1973).

${ }^{16 \times}$ Id. at 869, 306 N.E.2d at 599.

${ }^{169}$ But see Portland Cement Ass'n v. Ruckelshaus, 486 F.2d 375, 389 (D.C. Cir. 1973).

1708 Ill. App. 3d 1018, 290 N.E.2d 892 (4th Dist. 1972); accord, Armstrong Chemcon, Inc. v. PCB, 18 Ill. App. 3d 753, 310 N.E.2d 648 (1st Dist. 1974). 
controlling what flows into a sewer treatment plant and what flows out of that plant and pollutes the waters of the State"; because "controlling what goes into a sewer system is a practical method of controlling the final effluent," the regulations came within the general authority to adopt regulations to achieve such purposes as preventing pollution of the ultimate receiving stream. This decision underlines the statutory admonition that the sample types of regulations explicitly listed are not to be taken as exclusive; the Board has power to do whatever, consistent with other statutory requirements, is necessary to prevent pollution. Staley is thus a powerful precedent for sustaining recent Board regulations requiring consolidation of sewage treatment plants in suburban DuPage County on the grounds that small plants cannot provide adequate assurance of continuous satisfactory operation and that, because of their high cost per unit of waste treated, small plants make pollution more probable by squandering limited funds available for control purposes. ${ }^{171}$

Several decisions deal essentially with questions of whether particular regulations, of types clearly within the Board's authority, so erroneously balance the relevant considerations as to be arbitrary and thus illegal. The state supreme court was quite perfunctory in its treatment of the one such issue it has resolved. In the Coal Operators case, ${ }^{172}$ noted above, it was argued that the noise regulations were substantively arbitrary in that they prevented noise that was not unreasonable; the court rather surprisingly responded, without discussing either the regulations or the facts supporting them, that the Board had followed proper procedure:

The Board adopted its regulations only after their having been proposed by the qualified group which composed the Task Force on Noise and its consultants and only after 16 public hearings had been held by the Board extending for a period of almost a year. We cannot say that the rules which resulted from this study are clearly arbitrary, unreasonable or capricious. ${ }^{173}$

The First District appellate court was similarly deferential in Armstrong Chemcon, Inc. v. $P C B,{ }^{174}$ upholding a regulation limiting mercury discharges to 0.5 parts per billion. The court quoted exten27, 1974).

${ }^{17}$ In re DuPage County Wastewater Regionalization, No. R70-17 (P.C.B., filed Sept.

172 Illinois Coal Operators Ass'n v. PCB, 59 Ill.2d 305, 319 N.E.2d 782 (1974).

${ }^{173}$ Id. at 310,319 N.E.2d at 785.

17418 Ill. App. 3d 753, 310 N.E.2d 648 (1974). 
sively from testimony establishing that mercury was highly poisonous but referred to nothing that sustained the particular level set by the regulation. In fact the Board, in one of its earliest rulemaking actions, had had little evidence either that the prescribed level was dangerous or that it was achievable; the number represented the apparent background level in Lake Michigan and the limit of effective measurement techniques. ${ }^{175}$

These opinions demonstrate far greater deference to Board actions than is consistent with meaningful judicial review. That proper procedures have been followed by no means assures that the Board gave appropriate weight to the costs and benefits of compliance with its standards, as the statute requires it to do; and that mercury is poisonous does not mean the Board can do whatever it likes about mercury without regard for costs and benefits. Possibly the explanation of the Coal Operators opinion is found in the court's observation that the argument of arbitrariness was "generally stated"; if the objecting party did not demonstrate in what respects the rules were substantively arbitrary, perhaps it was not for the court to dig around in the record on its behalf.

To be sharply contrasted with Coal Operators and with Armstrong Chemcon is the more recent decision of the First District in Commonwealth Edison Co. v. $P C B,{ }^{178}$ striking down the particulate and sulfur-oxide emission standards applicable to electric power plants as arbitrary and unreasonable. The court's conclusion that the record failed to show that the Board "took into account" the feasibility of achieving compliance ${ }^{177}$ was surely hyperbole; the Board devoted, for example, two pages to summarizing and drawing conclusions from the evidence on technology for controlling sulfur emissions. ${ }^{178}$ The essence of the court's holding on feasibility seems rather to have been that the Board had acted arbitrarily in concluding that compliance was feasible. The court said the record showed

${ }^{173}$ In re Mercury Regulations, 1 P.C.B. 411 (1971). Actually, the regulation was not enforced as written; principal mercury dischargers were granted variances requiring them to take specific actions found economically reasonable and sufficient to avoid health hazards. Monsanto Co. v. EPA, 3 P.C.B. 9 (1971); Sherwin-Williams Co. v. EPA, 3 P.C.B. 37 (1971). In effect, therefore, the regulation required dischargers to carry the burden of contriving a plan for the best practicable control of mercury. A regulation so written might well have been justified by the extremely hazardous, nondegradable, biologically concentratable nature of the material, since the Board did not have enough information to set a rational effluent standard. The fact that the objecting companies in Armstrong Chemcon had received these variances raises a serious question as to their standing to object to the regulation as written, which they were not required to meet.

176 25 Ill. App. 3d 271, 323 N.E.2d 84 (1st Dist. 1974).

177 Id. at 288,323 N.E.2d at 95.

${ }^{178}$ In re Emission Standards, 4 P.C.B. 298, 331-33 (1972). 
that low-sulfur coal was not a viable means of meeting the standards, because of its "great cost," because not everyone could obtain it, and because of the testimony of one witness that "it is my understanding that the low-sulfur coal will . . . decrease the collection efficiency of certain installed electrostatic precipitators." As for devices that remove sulfur from stack gases after high-sulfur coal is burned, the court noted that "the Board recognized that operating problems had been shown to exist in some of the systems and that the performance guarantees made by the manufacturers of the equipment were riddled with conditions" and paraphrased the testimony of one witness that such devices "either had specific limitations or required further development." The court's conclusion: "The hearings revealed that the principles of sulfur removal were known but that their application was not."179

The Board's opinion had pointed out that "Commonwealth Edison has testified that it will be able to obtain sufficient Western coal of less than $1 \%$ sulfur content to comply throughout the Chicago region with our standard some time in 1974." It had referred, as the court acknowledged, to evidence on a successful Swedish stack-cleaning installation, on numerous large-scale demonstration projects, and on the availability of such devices on the market. It had said the dispute was "not significantly over issues of fact; it was over the ultimate question of judgment, which it is this Board's obligation to decide, as to whether on the generally agreed state of the technology it is appropriate to require the installation of sulfur removal devices . . . beyond those already undertaken to be built." Recognizing the existence of operating problems, the Board had set a compliance date embracing more than the expected time needed for construction "to permit nearly a year of further information to be accumulated before commitments must be made." It had added that, given serious violations of the health-related air-quality standards for sulfur in certain parts of the state, it would be folly to wait until all operating problems were solved. It had agreed with another expert witness, not cited by the court, that "on the admitted facts the development of sulfur control technology has advanced to the point where we are justified in requiring additional installations to be made, in areas suffering from serious sulfur problems." At the same time, in recognition of the novelty of control technology and the undesirability of diverting scarce low-sulfur fuel from areas where it was most needed, the Board had made its standard applica-

17925 Ill. App. 3 d at $286-87,323$ N.E.2d at $94-95$. 
ble only in three metropolitan areas. ${ }^{180}$

Having written the Board's opinion, I cannot claim objectivity; but I would have thought that the exercise of judgment on such questions of policy was precisely what the Board was for and that the court essentially substituted its judgment for that of the Board on a highly debatable matter.

Still more problematical was the court's action in striking down the particulate regulation, for the court never said in what respects the record was insufficient to demonstrate that compliance was feasible. The Board had specifically pointed out that "Commonwealth Edison Co. conceded that $99.5 \%$ collection efficiency was feasible" and "that it had ordered a 99.5\% precipitator for its new Powerton 5 plant," and that the testimony showed only 98.5 percent efficiency was necessary to meet the standard. ${ }^{181}$ The court did rely on rather tentative, uncorroborated testimony that the use of low-sulfur coal might impair performance, ${ }^{182}$ but the invalidation of the sulfur standard should have mooted whatever force there was in that objection. Perhaps the deficiency in the standard is indicated by the court's general statement, not tied specifically to the particulate provision, that it is not enough to show that "a single individual emission source can conform technically and economically to the rules"; the record must permit the inference that "it [is] technically feasible and economically reasonable for a substantial number of the individual emission sources in this state to comply." 183 I should have thought that, in the absence of contradiction, a single complying source would permit such an inference, or at least that the Board, which presumably is experienced in such matters, could reasonably so conclude. As the Board's opinion says, the very company that sued to set aside the particulate regulation had conceded the feasibility of meeting it; the Board's opinion dealt summarily with what was not disputed. It will be possible for the Board in the future to satisfy the court's requirement by insisting on redundant evidence and by writing longer opinions, but at additional administrative costs that seem to me wholly unwarranted.

On the question of cost, the court's opinion has more to recommend it. The Board was aware of the costs and implicitly deemed them reasonable, for there were cost figures in the record for control of both sulfur and particulates. But the opinion was careless; as the

\footnotetext{
$1 \times 0$ 4 P.C.B. at $331-35$.

$1 \times 14$ P.C.B. at 322.

$1 \times 225$ Ill. App. $3 \mathrm{~d}$ at 286,323 N.E.2d at 94.

183 Id. at 282,323 N.E.2d at 90.
} 
court said, it unaccountably reported no figures. For particulates it took as decisive that Edison was installing equipment that would meet the new standard at a new plant without being required to, and that a number of existing plants were being controlled "to levels far beyond the requirements of present regulations." Cost was further taken into account in permitting a somewhat looser standard "for those who have recently made substantial expenditures in order to bring their emissions close to but not quite within those permitted by the new general rule." 184 As for sulfur, the Board thought Edison's apparent commitment to purchase low-sulfur coal for its Chicago-area plants showed that the plan was economically reasonable to the extent that such fuel was obtainable. But the Board gave only its conclusion that the costs of stack control were acceptable: "The issue of what requirements are reasonable is one that can be resolved only by balancing the benefits of the contemplated rule against its costs . . . . Greater costs may be justified ... when the need for pollution abatement is greater. . . . In the Chicago, St. Louis, and Peoria regions . . . larger coal users can be expected either to utilize low-sulfur coal, as Commonwealth Edison is doing, or to construct additional facilities for the removal of sulfur dioxide at the stack . . . ." 185 Thus the Board's opinion fell far short of setting forth the costs of achieving compliance with either regulation and arguably was subject to reversal for failure to give an adequate explanation of the order.

But the cost information was in the Board's record, and a more sympathetic court might have inferred, without too much conjecture, that the Board had considered those costs reasonableassuming the record information was called to the court's attention. Care should be taken not to transform the Board's own salutary requirement that it write an opinion explaining its regulations $^{186}$ into an unduly burdensome one. In a complex rulemaking proceeding involving dozens of proposed regulations, hundreds of witnesses, and thousands of pages of evidence, one cannot expect the Board to dispose of every possible objection as thoroughly as in a simple enforcement case. Although the District of Columbia Circuit may have been too lenient in holding that the Administrative Procedure Act's requirement of a "concise general statement" of the basis and purpose of regulations was satisfied by a statement that said nothing at all about why the challenged figure was chosen,

1814 P.C.B. at $322-24$.

18 Id. at $330-33$.

Is PCB Regs., ch. 1, Rule 212. 
there is wisdom in that court's caution that "particularly as applied to environmental regulations, produced under the tension of need for reasonable expedition and need for resolution of a host of nagging problems, we are loath to stretch the requirement of a 'general statement' into a mandatie for reference to all the specific issues raised in comments." 187

Of utmost concern, should they ever be accepted by the appellate courts, are the approach and the holding of the Cook County circuit court, later set aside as premature, in Roth-Adam Fuel Co. v. $P C B .{ }^{188}$ The trial court held that a proposed rule (later adopted) effectively banning the use of coal for the heating of small residential or commercial buildings would take without compensation the property of coal dealers and of building owners. ${ }^{189}$ The reasoning behind this conclusion is less than clear. After reciting testimony indicating that the rule would decrease property values, might force poor tenants to move and owners to abandon their buildings, and might put coal merchants out of business, ${ }^{190}$ the court cited decisions requiring compensation for damage done by low-flying airplanes and opined that the rule "is palpably unconstitutional in that it provides for no just compensation to plaintiffs on account of the destruction of their substantial property rights."191

If the notion is that government may do nothing that imposes costs on a property owner or lowers the value of his land without paying compensation, it contravenes the whole history of authoritative interpretations of both federal and state taking provisions. For example, Mugler $v$. Kansas ${ }^{192}$ rejected the argument that a Kansas law forbidding the manufacture or sale of beer was a taking of the property of brewers under the federal law:

The power which the States have of prohibiting such use by individuals of their property as will be prejudicial to the health, the morals, or the safety of the public, is not-and, consistently with the existence and safety of organized society, cannot be-burdened with the condition that the State must compen-

${ }^{187}$ Kennecott Copper Corp. v. EPA, 462 F.2d 846, 850 (D.C. Cir. 1972). The court found an independent basis for requiring some explanation of the figure chosen, but it is by no means clear that it would have required more of an explanation than was given by the Illinois Board in Commonwealth Edison.

${ }^{3 \times 4} 4$ E.R.C. 1189 (1972), rev'd, 10 Ill. App. 3d 756, 295 N.E.2d 321 (1st Dist. 1973).

189 The opinion did not suggest that any of the latter class were plaintiffs and thus overlooked a serious question of standing.

1904 E.R.C. at 1190-91.

1914 E.R.C. at 1191, 1194.

192123 U.S. 623 (1887). See also Goldblatt v. Town of Hempstead, 369 U.S. 590 (1962). 
sate such individual owners for pecuniary losses they may sustain, by reason of their not being permitted, by a noxious use of their property, to inflict injury upon the community. ${ }^{193}$

The Illinois supreme court, similarly, has upheld innumerable regulations imposing significant costs upon property owners. ${ }^{194}$ The contrary theory would invalidate all pollution regulations. Nor does the mere fact that a regulation may put someone out of business transform it into a taking of property, as Mugler again shows. ${ }^{195}$ The airplane cases cited in Roth-Adam ${ }^{196}$ are easily distinguishable. There the government was benefiting in its proprietary operations from the impairment of the plaintiffs' property, and there was nothing harmful about the plaintiffs' use of their land. The coal-burning regulation, like other pollution rules, is a straightforward example of a prohibition on using one's property so as to injure others.

A more charitable interpretation of the Roth-Adam opinion is that the court applied the equivalent of a substantive due process test, holding the regulation invalid because it was unreasonable in its balance of costs and benefits. Thus the court declared that the Board "did not determine whether it would be economically feasible for coal users to comply" with the proposed rule and that there was no evidence to support "the economic fairness and feasibility" of singling out residential and commercial coal users for especially strict treatment. ${ }^{197}$ That the overall reasonableness of a regulation is the test of its federal constitutionality is by no means clear, especially in light of Supreme Court decisions during the past forty years sharply limiting the scope of judicial inquiry into reasonableness under the rubric of substantive due process. ${ }^{108}$ The Illinois supreme

193123 U.S. at 669.

${ }^{194}$ E.g., Kaukas v. City of Chicago, $27 \mathrm{Ill.2d} \mathrm{197,} 188$ N.E.2d 700, appeal dismissed, 375 U.S. 8 (1963) (requiring the construction of additional exits from existing dwellings in case of fires). The decision was not, as suggested by the Roth-Adam trial court, based exclusively upon the lack of clean hands; that doctrine was used to rebut the distinct argument that the city was estopped by having issued a permit. See also City of Chicago v. Miller, 27 Ill.2d 211, 188 N.E.2d 694 (1963) (upholding additional health and safety requirements on existing buildings).

195 See also Hadacheck v. Sebastian, 239 U.S. 394 (1915). See generally Sax, Takings and the Police Power, 74 Y ALE L.J. 36 (1964), and cases cited. Regarding the Illinois constitution, compare City of Chicago v. Birnbaum, 49 Ill.2d 250, 274 N.E.2d 22 (1971), upholding the demolition of buildings for safety reasons.

198 E.g., Griggs v. Allegheny County, 369 U.S. 84 (1962).

1974 E.R.C. at 1190, 1194.

${ }^{198}$ See, e.g., North Dakota State Bd. of Pharmacy v. Snyder's Drug Stores, Inc., 414 U.S. 156 (1973). A conspicuous exception to this pattern, but significantly outside the area of property regulation, is the abortion case of Roe v. Wade, 410 U.S. 113 (1973). The opaque opinion in Goldblatt v. Town of Hempstead, 369 U.S. 590 (1962), leaves room for the possibil- 
court has been more susceptible to such claims under the state constitution, ${ }^{199}$ but its test of reasonableness in light of costs and benefits appears in any event to be the same as the test of statutory validity. ${ }^{200}$ Judged by either a constitutional or a statutory standard, the trial court decision in Roth-Adam seems to this biased observer another instance of unwarranted substitution of judicial for administrative judgment; the Board's proposed opinion attempting to justify the rule, which is quoted earlier in this paper, was before the court. ${ }^{201}$

The appellate court in Commonwealth Edison also struck down the regulation outlawing unjustifiable degradation of the air in areas cleaner than required by air-quality standards. ${ }^{202}$ The court contended that this provision in effect authorized the Agency, in administering the standard through its permit program, "to create a new ambient air quality standard." Accordingly, said the court, the rule was invalid because it attempted to delegate the Board's rulemaking authority to the Agency. ${ }^{203}$ This startling conclusion could be applied with equal force to invalidate any regulation leaving any area of judgment to the Agency in granting permits: the authority to refuse permits for violation of the air-quality standards, or of the statutory nuisance provisions, or of the regulation forbidding unreasonable noise; the power to determine the appropriate size of a mixing zone; the power to ascertain whether effluent streams may be combined for treatment; the power to determine what credit to give for background concentrations. In every example the Agency is to make a case-by-case determination by applying the standard designated by the Board to the facts. That is not what I understand to be rulemaking. ${ }^{204}$ Moreover, the court overlooked the statutory

ity of a more stringent test under the takings clause when real property is involved, but does not resolve the question; no such balancing was undertaken in Mugler v. Kansas.

${ }^{199}$ See, e.g., Sulzberger v. County of Peoria, 29 Ill. 2d 532, 194 N.E.2d 287 (1963) (refusal to rezone for commercial use invalid on facts because diminished value without public benefit); Kaukas v. City of Chicago, 27 Ill. 2d 197, 201, 188 N.E.2d at 700, 702 (1963) ("[T]he question . . . is . . . whether the property owners affected suffer unreasonable exactions as compared with the resulting public benefits.").

${ }^{200}$ See text and notes at notes 2-7 supra.

201 See text and notes at notes 130-31 supra. The Board's opinion also suggested reasons for adopting a more stringent rule to small residential and commercial sources and for limiting the rule to Chicago, in possible anticipatory response to the discrimination argument hinted at in the court's opinion.

${ }^{202}$ See text and note at note 150 supra.

${ }^{203}$ Commonwealth Edison Co. v. PCB, 25 Ill. App. 3d 271, 279, 323 N.E.2d 84, 88-89 (1st Dist. 1974).

${ }^{204}$ Cf. NLRB v. Bell Aerospace Labs., Inc., 416 U.S. 267 (1974), holding the Board could make law in the process of adjudication without following the rulemaking procedures of the Administrative Procedure Act. 
provision ${ }^{205}$ making the denial of a permit reviewable by the Board. Just as when it files a complaint, the Agency in a permit proceeding only makes the initial decision that there is a violation of the regulation; it is the Board that will ultimately decide whether there has been unjustifiable degradation. If the view taken by the appellate court in Edison prevails, it is difficult to see how the state can deal with any kind of pollution for which it is premature to develop numerical standards.

\section{CoNCLUSION}

The first five years of experience under the Illinois Environmental Protection Act have demonstrated its basic flexibility in enabling the Pollution Control Board to engage in rulemaking necessary to combat pollution. They have also exposed a few badly drafted statutory provisions, a few examples both of excessive and of insufficient judicial scrutiny, and a number of recurring practical difficulties in the drafting of standards. Perhaps most significant among the last is the perennial insufficiency of information, despite yeoman efforts in some cases by the Agency and by the Institute, to permit anything remotely resembling a full comparison of costs and benefits. While it is hoped that all concerned will continue to strive for better information, I suspect that the problem is inherent in the nature of the subject. We should be alert to improve the regulations when we obtain better knowledge, but it would be the height of folly to do nothing until we knew everything-for it seems likely that we would do ourselves enormous and unjustified harm while waiting.

${ }^{205} \S 40$. 